\title{
PROBABILISTIC ASSESSMENT OF THE SEISMIC PERFORMANCE OF STEEL BUILDINGS DESIGNED ACCORDING TO THE LRFD SPECIFICATION
}

\author{
C. A. Bermúdez ${ }^{1}$, J. E. Hurtado ${ }^{2}$, L. G. Pujades ${ }^{3}$, A.H. Barbat ${ }^{4}$ and J.R. González- \\ Drigo $^{5}$ \\ ${ }^{1}$ alberto.bermudez@upc.edu, ${ }^{2}$ jehurtado@unal.edu.co \\ Universidad Nacional de Colombia, Apartado 127, Manizales, Colombia. \\ 3.lluis.pujades@upc.edu, ${ }^{4}$ alex.barbat@upc.edu, ${ }^{5}$ Jose.Ramon.Gonzalez@upc.edu \\ Universitat Politecnica de Catalunya. C/. Gran Capitá, s/n, Barcelona, Spain.
}

\begin{abstract}
Seismic regulations and building codes experienced major advances in the last decades. Nevertheless, current trends in earthquake engineering are the assessment of the computational procedures provided by such design rules, by using probabilistic techniques, in order to test the anticipated levels of reliability and performance of the structures. While some consideration is given in codes to the uncertainties associated to the seismic action, no probabilistic requirements are posed on the responses, which determine the final design. Consequently, the risk associated to the design formulas remains unknown. The objective of this chapter is to study whether steel buildings designed and constructed according to the Load and Resistance Factor Design (LRFD) specification for Structural Steel Buildings, reasonably meet the probabilistic requirements on structural member safety applying non-linear dynamic analyses and Monte-Carlo techniques. Starting from a specific low-rise braced frame steel building existing in Manizales, Colombia, we also analyze mid-rise and high-rise braced frame buildings. Similar low-mid-and high-rise Moment-resisting frame buildings are also studied. For each building we performed more than ten thousand dynamic simulations, covering a wide range of combinations of demand and strength. In this way, we determine the exceedance probability of the construction capacity and we verify the safety and reliability of the structural members of the buildings. In the analysis of demand, we consider the probabilistic variation of the vertical gravity loads as well as of the seismic horizontal ones. The analyses of the strength of the studied buildings take into account the uncertainties and probability distributions of several parameters as: the yielding strain, the elasticity modulus, the cross-sectional area and their inertia moments. The analysis shows that in the cases here analyzed, but especially in moment-resisting frame buildings, the uncertainties in the input parameters may lead to significant failure probabilities. We conclude that braced frame steel buildings fulfil the seismic safety requirements while moment-resisting frame buildings would require a safety factor of about 2.7 for the column anchorages to the foundations.
\end{abstract}

Keywords: probabilistic assessment, limit states, stochastic analysis, seismic vulnerability, fragility, steel buildings, strength degrading, non-linear analysis. 


\section{Introduction}

The major part of losses due to earthquakes has its origin in the deficient seismic behaviour of buildings which generates different levels of structural damage or even collapse. The damage level expected during earthquakes in buildings is greatly influenced by the code applied in their design and by the construction procedures and practices usual in the affected area, which decisively influence on their seismic vulnerability. Obviously, the advances in earthquake engineering and in the seismic design codes have a positive effect on the design of new buildings, and recent postearthquake evaluations show an improvement of the structural behaviour of modern buildings. But, in the urban areas of the world, there are many old existing structures without an adequate seismic design; these structures have been constructed or designed in the past, possibly with earthquake resistant design codes which are obsolete nowadays or even without the use of any code. This fact influences decisively on the overall vulnerability and risk of urban areas and catastrophic losses occurred in many countries during strong earthquakes in the last fifteen years. In this

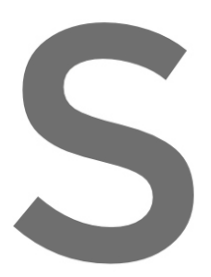
Sense, the cases of the earthquakes of Northridge (UJSA,
Kocaeli (Turkey, 1999), Nantou (Taiwan, 1999), K
Niigata (Japan, 2007), Wenchuan (China, 2008) and 1'A
cited among others.
The physical seismic vulnerability can be defined as

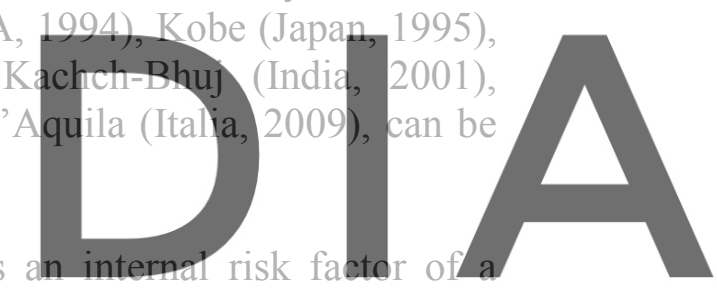

structure exposed to an earthquake and corresponds to its intrinsic predisposition to

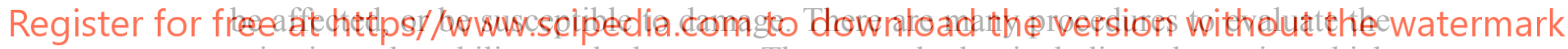
seismic vulnerability and damage. These methods, including those in which earthquakes are defined in terms of macroseismic intensities, and some practical applications to urban areas are well described [1, 2, 3, 4, 5, 6, 7 and 8]. Vulnerability and fragility of existing buildings can be also evaluated from capacity curves, which are force-displacement diagrams, generally corresponding to the maximum response of structures in the fundamental mode of vibration. They allow describing the structural seismic performance, especially the expected damage, and they are obtained by means of nonlinear structural analyses. Capacity spectrum based techniques have been also applied to evaluate the seismic performance of reinforced concrete building with waffle slabs [9 and 10]. In seismic urban areas, there are many buildings with different levels of seismic vulnerability and some of them show an inadequate behaviour during earthquakes. For this reason, many recent earthquake engineering studies are oriented towards the development, validation and application of techniques, which increase the seismic capacity of buildings and allow to take better decisions on the seismic vulnerability and risk. Some of these techniques are based on procedures which accurately estimate the seismic capacity and the seismic risk of the buildings. In this category fall seismic vulnerability and risk estimation methodologies like HAZUS 1999 and RISK-UE, as well as seismic risk studies using computational models for nonlinear structural analysis ([11, 3 and 
4] providing capacity and fragility curves. In this same direction go some of the works of the Joint Committee of Structural Safety (JCSS). Faber reviews important issues related to risk assessment in engineering and discusses about the use of stochastic methods in civil engineering analyses [12 and 13].

It has to be pointed out that, when the seismic behaviour of a building is evaluated, uncertainties are high in both the seismic hazard of the site and the vulnerability of the building. Therefore, the main purpose of this chapter is to perform a probabilistic analysis of an existing building of Manizales, Colombia designed by using the Load and Resistance Factor Design (LRFD) specification for Structural Steel Buildings [14]. To do that, two alternative design proposals, namely moment-resisting frames and braced frame structures are considered. Monte Carlo simulation is applied to analyze the seismic safety of these structures. The random nature of the seismic action and that of the parameters describing the strength of the steel structures are taken into consideration. The seismic action was modelled as a non-stationary signal in time and frequency. In our simulations, the probability distribution for the effective peak ground acceleration (epga) has been defined in such a way that the corresponding one of the design earthquake has a $10 \%$ of probability of being exceeded. The statistical distributions for the parameters describing the strength of the steel structures are determined from statistical analyses of the American Institute

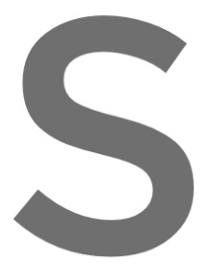
of Steel Construdtion (AISC) formylas allowing determining the type of distribution as well as their mean values and standard deviations. RUAUMOKO domputer code $[15]$ wa
analyses. In these computations the stre Prestandard and Commentary for the Seismic Rehabilitation of Buildings FEMA

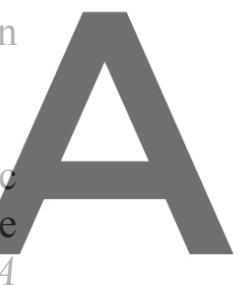

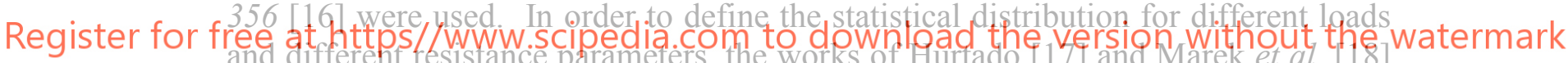
have been used. The main limit states reached by the buildings are compared with the code provisions. In this way, the structural behaviour under synthetic seismic events generated according to both the seismic features of the construction site and the seismic hazard level for which the buildings were designed, is evaluated. Thus, this study determines the probability of exceedance of the structural members' capacity and, consequently, the safety levels of these types of buildings.

\section{Highlights of LRFD specification}

The primary objective of the LRFD specification [14] is to provide reliability conditions for steel structures under various loading conditions and it uses separate factors for each load and strength conditions. Because these different factors reflect the degree of uncertainty of different loads and combinations of loads and the accuracy of predicted strength, a uniform reliability is possible [14]. The required strength and the design strength in the LRFD specification are related by the following equation: 


$$
\Sigma \gamma i Q i \leq \phi R n
$$

where $Q i$ are load effects, $\gamma i$ are their respective load factors, $R n$ is the nominal strength and $\phi$ is a resistance factor [14]. In the following, we describe some limit states included in the LRFD specification together with the equations to be fulfilled by the elements and structural members as well as by the entire building.

\subsection{Limit state of tension rupture of the anchor rods}

The anchor rods are designed according to the limit state of tension rupture at the effective section. The following equation must be verified:

$$
\mathrm{M}_{\mathrm{BASE}} \leq \mathrm{d} \cdot \mathrm{T}
$$

where $\mathrm{M}_{\mathrm{BASE}}$ is the maximum moment at the base of the column, $d$ is the distance between the centres of the anchor rods (see Figure 1) and $\mathrm{T}$ is the tensile force in anchor rods due to service loads. When a base plate has 4 anchor rods, as shown in Figure 1, the total tensile force is the addition of the tensile forces acting in 2 anchor rods. The tension strength of each anchor rod is given by
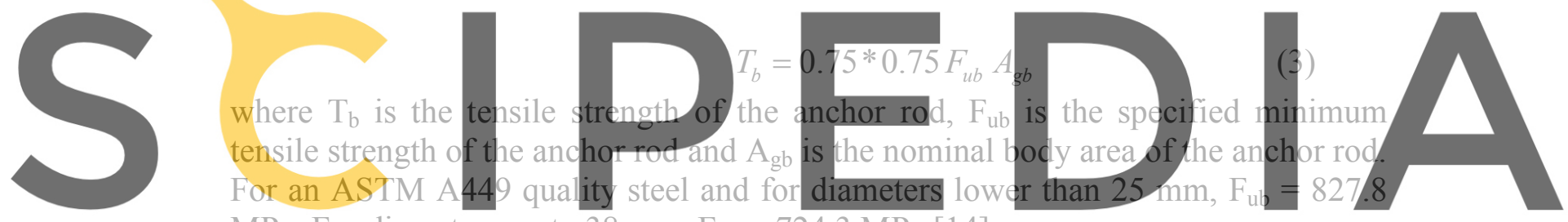

$\mathrm{MPa}$. For diameters up to $38 \mathrm{~mm}, \mathrm{~F}_{\mathrm{ub}}=724.3 \mathrm{MPa}[14]$.

Register for free at https//www.scipedia.com to download the version without the watermark

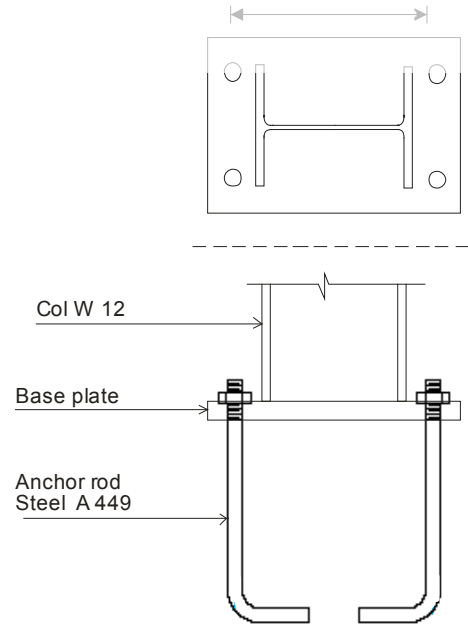

Figure 1. Detail of column anchorage to foundation. 


\subsection{Yielding limit state in the cross section of members under tension}

The design strength of members under tension involves different structural elements, connection plates and brackets composing a whole structure. The yielding limit state of the cross section is intended to prevent excessive elongation of the member. Usually, the portion of the total member length occupied by fastener holes is small. The effect of early yielding at the reduced cross sections on the total member elongation is negligible. The design strength for yielding in the cross section of members under tension must satisfy the equation

$$
T \leq 0.9 F_{y} A_{g}
$$

where $\mathrm{T}$ is the design strength of members under tension, $\mathrm{F}_{\mathrm{y}}$ is the specified minimum yield stress and $A_{g}$ is the cross area of the member. For an ASTM A-36 quality steel, $\mathrm{F}_{\mathrm{y}}$ is $248 \mathrm{MPa}$.

Other limit states like, for instance, the limit state of fracture at the section with the minimum effective net area and the limit state of block shear rupture, must be revised. But, in general, the limit state for yielding in the cross section may govern
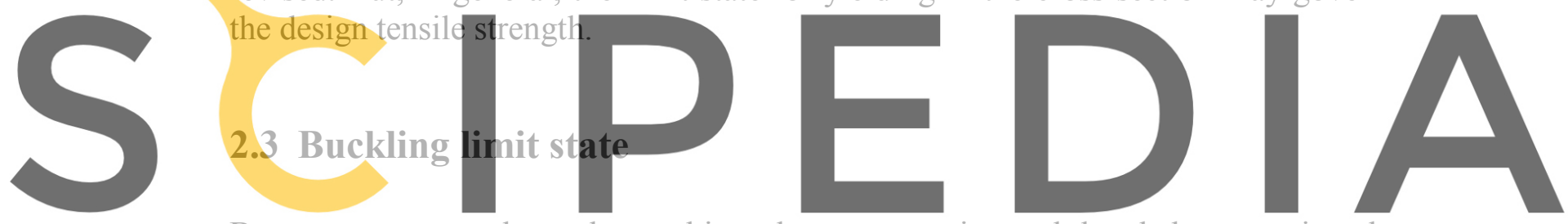

Braces are structural members subjected to compression and they behave as pinned-

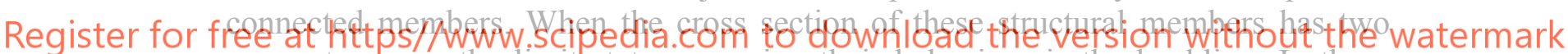
symmetry axes, the limit state governing their behaviour is the buckling. In these cases, the following equation must be verified:

$$
C \leq 0.85 A_{g} F_{C R}
$$

where $\mathrm{C}$ is the compressive force due to the corresponding loading combinations, $\mathrm{A}_{\mathrm{g}}$ is the cross section area of the member and $\mathrm{F}_{\mathrm{CR}}$ is the critical stress calculated as

$$
\begin{array}{rlr}
\mathrm{F}_{\mathrm{CR}} & =\left[0.658^{\lambda_{C}^{2}}\right] \mathrm{F}_{\mathrm{y}} & \text { if } \lambda_{\mathrm{c}} \leq 1.5 \\
F_{C R} & =\left[\frac{0.877}{\lambda_{C}^{2}}\right] F_{y} & \text { if } \lambda_{\mathrm{c}}>1.5 \\
\lambda_{c} & =\frac{K l}{\pi r} \sqrt{\frac{F_{y}}{E}}
\end{array}
$$

where $\mathrm{F}_{\mathrm{y}}$ is the specified yield stress, $K$ is the effective length factor, $l$ is the laterally un-braced length of member, $r$ is the rotation radius around the buckling axis and $E$ is the modulus of elasticity of steel which is 2,0 E+11 Pa. For ASTM A-36 quality steel, $\mathrm{F}_{\mathrm{y}}$ is $2.48 \mathrm{E}+08 \mathrm{~Pa}$. 
The limit state of bending-torsion buckling must be verified in the case of structural members having only one symmetry axis.

\subsection{Yielding limit states of beams under bending and shear}

The limit state of yielding under bending has to be considered for beams with compact cross section subjected to bending and having the lateral buckling restricted. Their bending yielding strength limit is given by the equation

$$
M \leq 0.9 M_{p}=0.9 Z \mathrm{~F}_{\mathrm{y}}
$$

where $M_{p}$ is the plastic moment, $Z$ is the plastic cross section modulus in the direction of bending; $F_{y}$ is the specified minimum yield stress of the type of steel.

The limit state of yielding of beams under shear is given by the equation

$$
V \leq 0.9 V_{n}
$$

where $V_{n}=0.54 F_{y} A_{w}$, is the nominal shear strength; $A_{w}=d t_{w}$ is the area subjected to shear; $d$ is the overall height of the beam cross section; $t_{w}$ is the beam web thickness; $F_{y}$ is the specified minimum yield stress of the type of steel. For ASTM
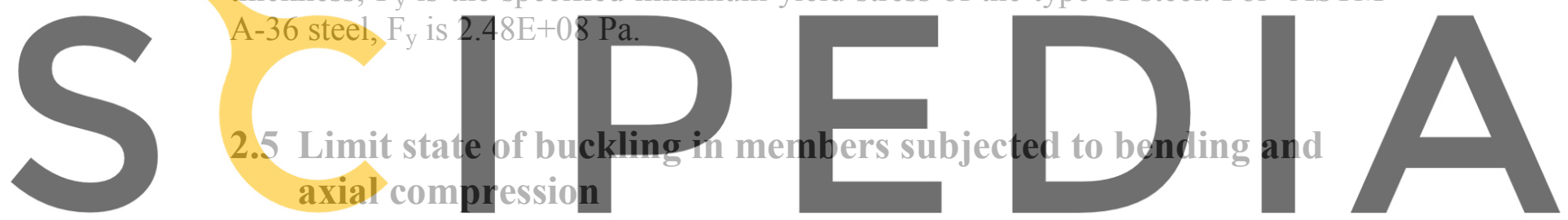

The interaction of compression and bending in beam-columns with one or two axes

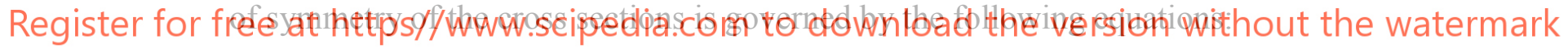

$$
\frac{\mathrm{P}_{\mathrm{u}}}{\phi_{\mathrm{c}} \mathrm{P}_{\mathrm{n}}}+\frac{8}{9}\left[\frac{\mathrm{M}_{\mathrm{ux}}}{\phi_{\mathrm{b}} \mathrm{M}_{\mathrm{nx}}}+\frac{\mathrm{M}_{\mathrm{uy}}}{\phi_{\mathrm{b}} \mathrm{M}_{\mathrm{ny}}}\right] \leq 1.0 \quad \text { for } \frac{P_{u}}{\phi_{c} P_{n}} \geq 0.2
$$

or,

$$
\frac{\mathrm{P}_{\mathrm{u}}}{2 \phi_{\mathrm{c}} \mathrm{P}_{\mathrm{n}}}+\frac{\mathrm{M}_{\mathrm{ux}}}{\phi_{\mathrm{b}} \mathrm{M}_{\mathrm{nx}}}+\frac{\mathrm{M}_{\mathrm{uy}}}{\phi_{\mathrm{b}} \mathrm{M}_{\mathrm{ny}}} \leq 1.0 \quad \text { for } \frac{P_{u}}{\phi_{c} P_{n}}<0.2
$$

where $\mathrm{P}_{\mathrm{u}}$ is the required compressive strength; $\mathrm{M}_{\mathrm{ux}}$ is the required bending strength in direction $x ; \mathrm{M}_{\mathrm{uy}}$ is the required bending strength in direction $y ; \mathrm{P}_{\mathrm{n}}$ is the nominal compressive strength. $\mathrm{M}_{\mathrm{nx}}$ is the nominal bending strength in direction $x ; \mathrm{M}_{\mathrm{ny}}$ is the nominal bending strength in direction $y ; \phi_{c}=0.85$ is the factor of strength under compression and $\phi_{\mathrm{b}}=0.9$ is the factor of strength under bending. 


\subsection{Limit state of lateral deflection}

According to the AISC specifications [14], the maximum inter-story drift of a building, that is the maximum difference between horizontal deflections of two consecutive stories, should not exceed the limit story drift established in the corresponding building construction code. Story drift shall be calculated using the appropriate load effects consistent with the structural system and the method of analysis. Limits of inter-story drifts shall be in accordance with the governing code and shall not impair the stability of the structure. The code used in this work is the Normas Colombianas de Diseño y Construcción Sismo Resistente NSR-98 [19]. In order to control the damage of steel structures and of their non-structural elements, this code establishes that the maximum lateral drift for frames is 0.01 . The interstory drift index is $\Delta_{o h} / L$, where $\Delta_{o h}$ is the story drift and L is the story height and is one of the design criteria avoiding structural and non-structural damage. Taking into account the seismic effect in the two principal directions of the analyzed building, the following equation is used to calculate the drift:

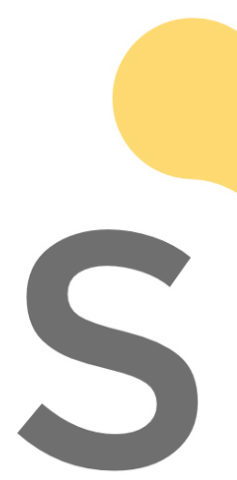
rat

Register for free at https//www.scipedia, com to download the version without the watermark 3. Analyzed steel buildings

A specific low-rise braced frame steel building existing in Manizales, Colombia, is first analyzed. In order to have a deeper insight on the seismic performance of steel buildings, an alternative design solution consisting of a similar low-rise momentresisting frame building is also studied. With the same purpose mid- and high-rise braced frame and moment-resisting frame buildings have been also extensively analyzed. For mid- and high-rise buildings neither the buildings description nor all the obtained results are given in this chapter; only the most relevant results and conclusions of their detailed study are discussed herein.

\subsection{Braced frame building}

The braced frame building is made of ASTM A-36 steel; it has concrete top slabs and a curved plan with an average radius of $114.5 \mathrm{~m}$ (see Figure 2). The crosssections are plotted in Figures 3 and 4. The distance among transversal frames ranges from 7.6 to $8.6 \mathrm{~m}$. Figure 5 shows the building under construction. In figures 3 and 4, four structural levels are observed. The fourth one, nevertheless, is shorter, 
as it does not have a top slab, but a lattice that supports the architectural members of the façade. The total height of the building is $11.94 \mathrm{~m}$.

Both, the outer and the inner infill walls are lightweighted. They have an inner core made of cold-bend galvanised steel members which are interconnected and fixed to the ground and to the ceiling of each storey; gypsum walls are then screwed to both sides of this core.

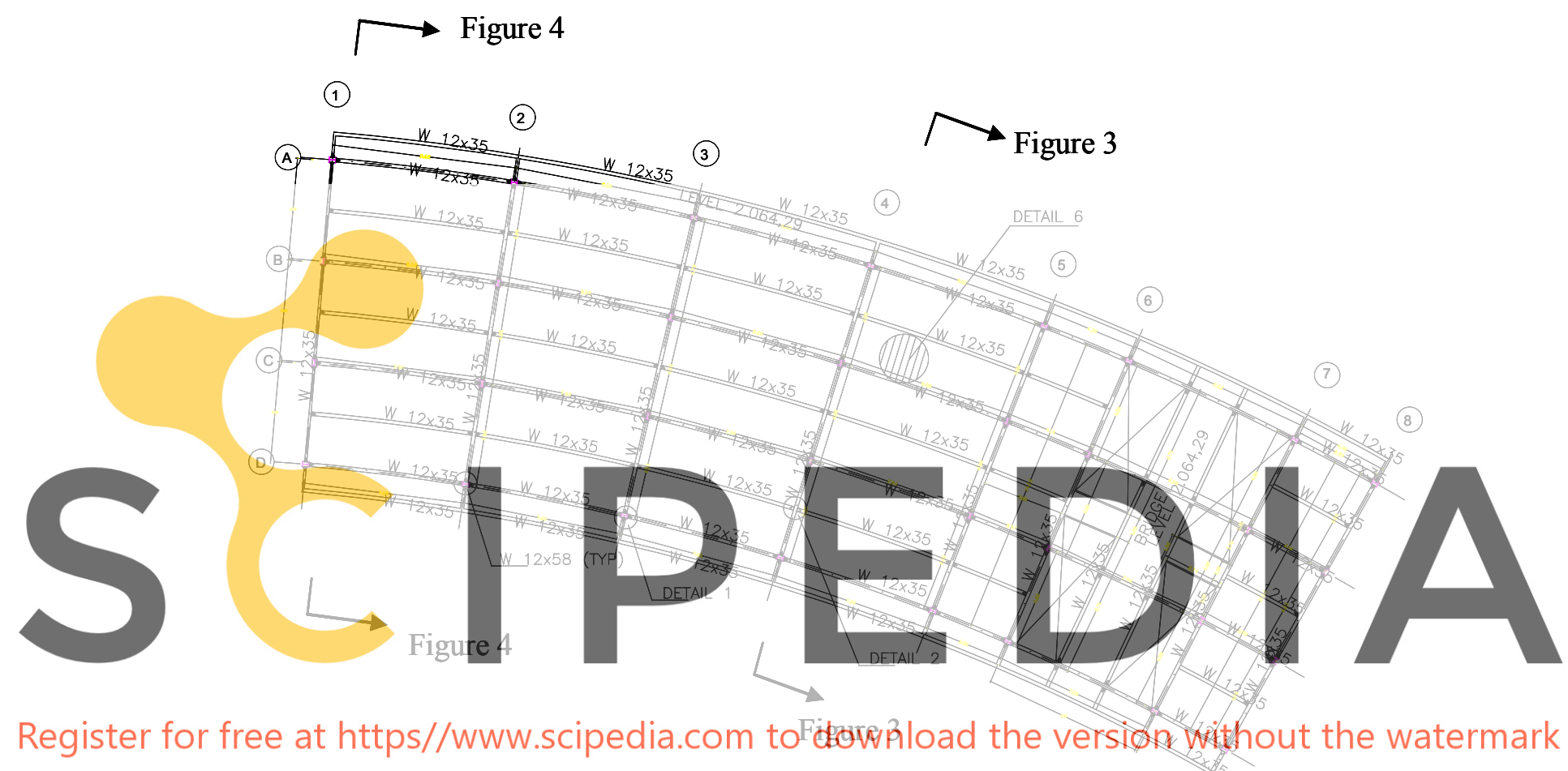

Figure 2. Plan of the building under study.

The top slab is placed on a 22-size galvanized steel layer with a reinforcement rip height of $0.05 \mathrm{~m}$ that works as a casing and a positive reinforcement of the top slab. The slab is thus reinforced in one direction and it has a maximum height of $0.10 \mathrm{~m}$. It is connected to the steel beams by $16-\mathrm{mm}$ diameter shear connectors, placed every $50 \mathrm{~cm}$ in order to ensure the monolithic behaviour of the steel beamconcrete slab joint.

The rigth side of Figure 5 shows that the columns are premoulded with elements at which ends thick plates are welded. Once the holes coincide, the beams are connected to these columns by means of eight high-strenght bolts. This construction method has the following advantages: easier quality control, prevention of the effect of variable weather conditions and, above all, possibility of choosing the most efficient welding position. On the construction site, only bracings are welded to connecting plates. Figure 6 shows some details related to these connections. 

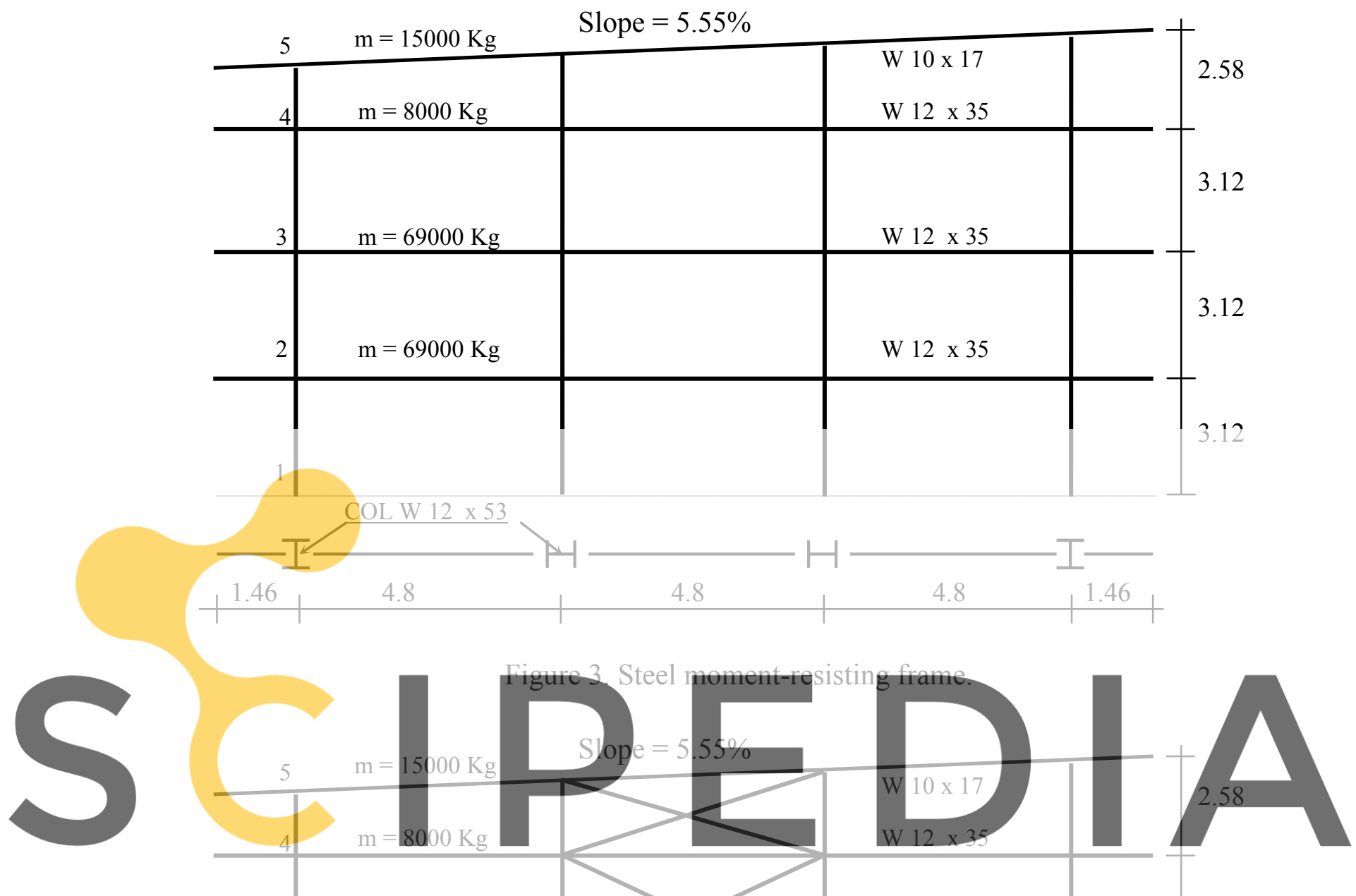

Register for free at https//www.scipedia.com to etownload the version without the Bvatermark

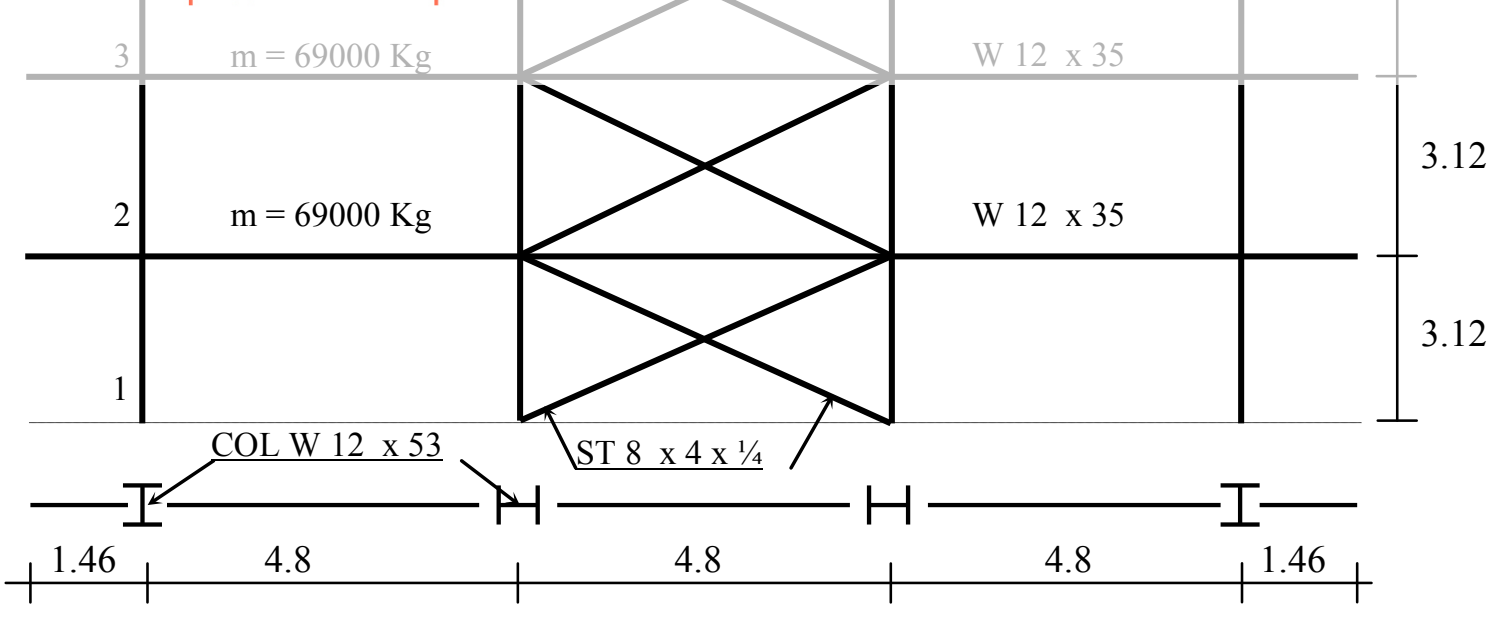

Figure 4. Steel braced frame 
The total permanent overload per cross frame is $1569 \mathrm{kN}$. Its geometry, mass distribution and structural sections is shown in Figures 3 and 4. Structural profiles are denoted according to the AISC. Thus, the cross section of profile W $12 \times 35$ is approximately $12 "(0.3048 \mathrm{~m})$ in height and weights 35 pounds per foot $(510.9$ $\mathrm{N} / \mathrm{m}$ ). Other values are expressed according to the International System (IS) units. The weights of each braced frame, including girders and connection plates, is about $229 \mathrm{kN}$ and, as it covers a useful area of $420 \mathrm{~m}^{2}$, the weight per constructed area is $545 \mathrm{~N} / \mathrm{m}^{2}$. The weight per volume unit is $143 \mathrm{~N} / \mathrm{m}^{3}$.

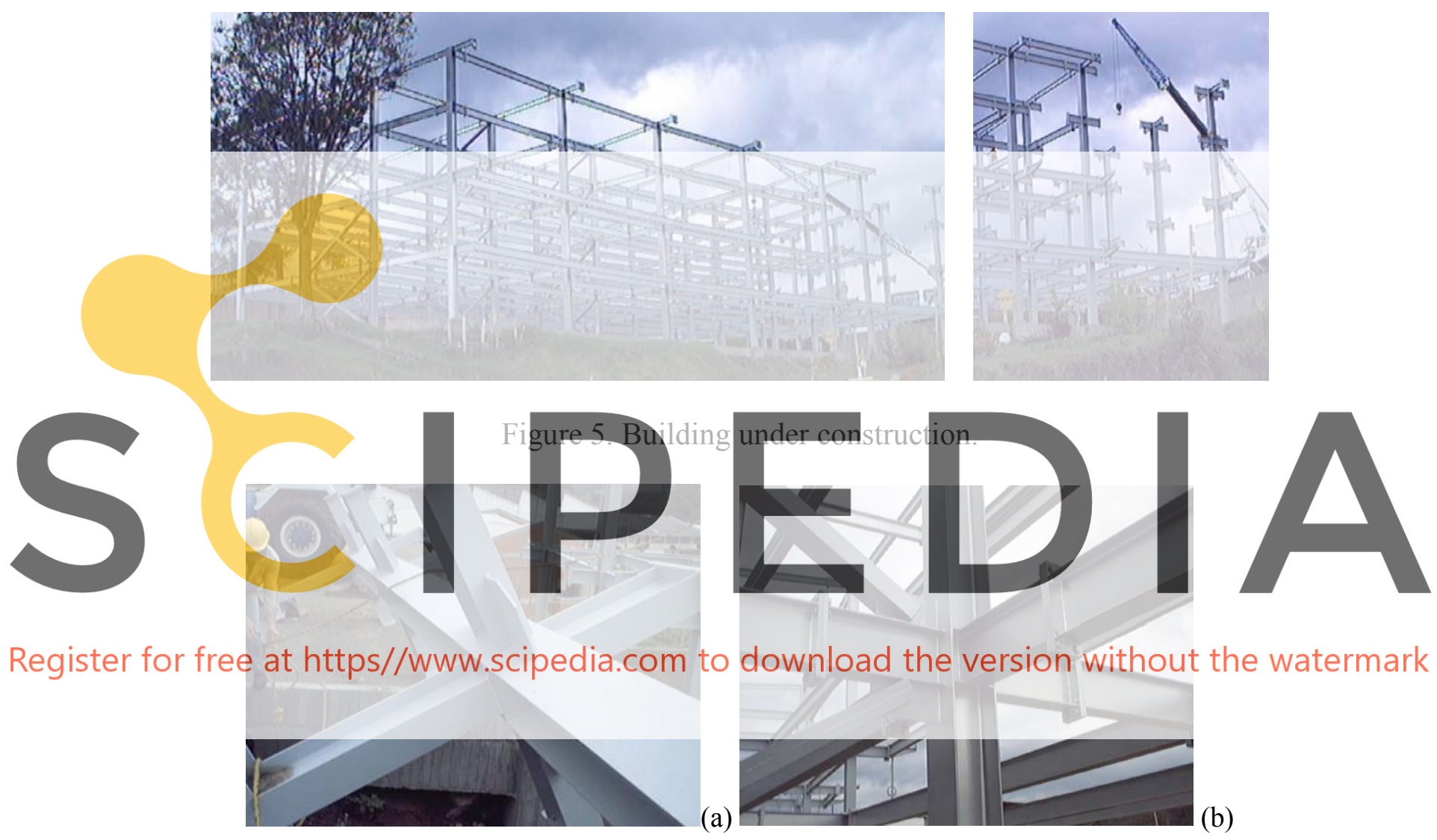

Figure 6. Detail of the columns (a) and of the connections (b).

The transversal frame to be studied is shown in Figure 7, which specifies all the members and their corresponding structural sections. The dashed line shows the members which are close to yielding. The maximum forces at the ends of each of these members were obtained. In each simulation, the axial load, the shear force and the bending moment of these members are calculated in order to evaluate the probability of exceeding their strength limit. In Figure 7, the braces have two numbers. This is because, for each cycle, the seismic motion acts in two directions, alternatively producing compression and tension forces in the braces. The capacity of these braces to resist forces, as well as their stress-strain diagram, is different. For this reason, each brace is modelled by two parallel members, one for compression and the other one for tension. The values representing the plastic behaviour of these 
braced frames are shown in Table 1 and are detailed in Figure 8. This figure shows the parameters used in FEMA 356 and the equivalent input parameters used by the computer code RUAUMOKO [15] in the non-linear analysis.

Table 1. Model parameters (see figures 7 and 8).

\begin{tabular}{|l|c|c|c|c|c|c|c|}
\hline $\begin{array}{c}\text { Member type } \\
\text { and bending } \\
\text { axis }\end{array}$ & Main stress & $\mathbf{a}$ & $\mathbf{b}$ & $\begin{array}{c}\mathbf{c}= \\
\text { RDUCT }^{\mathbf{1}}\end{array}$ & DUCT1 $^{\mathbf{1}}$ & DUCT2 $^{\mathbf{1}}$ & DUCT3 $^{\mathbf{1}}$ \\
\hline $\mathrm{W} 12 \mathrm{x} 53, \mathrm{XX}$ & Compression & 0.50 & 8.00 & 0.20 & 1.50 & 7.58 & 9.00 \\
\hline $\mathrm{W} 12 \times 53, \mathrm{YY}$ & Bending & 1.48 & 2.25 & 0.20 & 2.48 & 2.604 & 3.25 \\
\hline $\mathrm{W} 12 \times 35, \mathrm{XX}$ & Bending & 9.00 & 11.00 & 0.60 & 10.00 & 10.20 & 12.00 \\
\hline ST $8 \times 4 \times 1 / 4, \mathrm{YY}$ & Compression & 0.5 & 3.64 & 0.23 & 1.50 & 3.07 & 4.64 \\
\hline ST $8 \times 4 \times 1 / 4$ & Tension & 11.0 & 14.00 & 0.8 & 12.00 & 13.20 & 15.0 \\
\hline
\end{tabular}

${ }^{1}$ Input parameter to computer code RUAUMOKO.

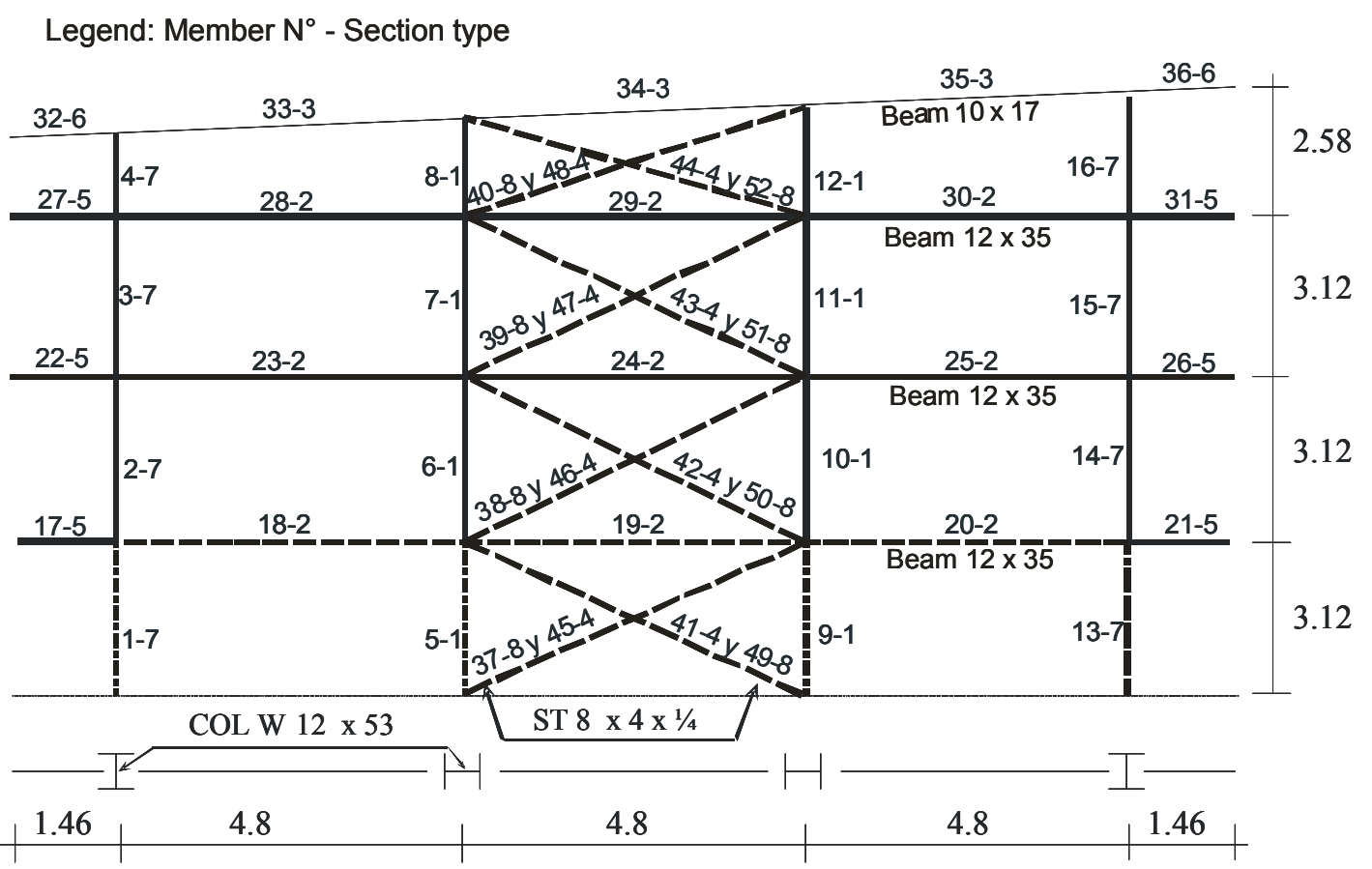

Figure 7. The braced frame analyzed 


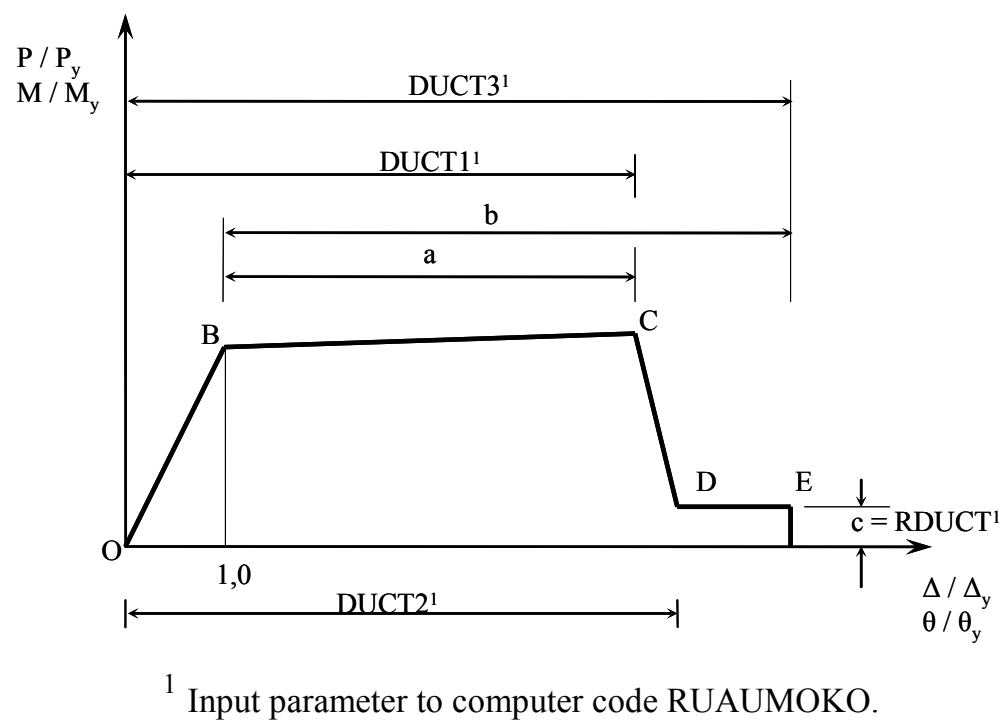

Figure 8. Moment-curvature relationship for a plastic hinge

\subsection{Moment-resisting frame building}

This building has the same geometry, load combinations and materials as the braced frame building, but all its frames were designed as moment-resisting frames according to the requirements of the LRFD specification. Special attention has been paid to the lateral deflection described in section 2.7. The dimensions of the building and the different structural members can be appreciated in Figure 9, where the members close to yielding are indicated with a dashed line. We calculated the maximum forces at the end of each member; that is, for each simulation, the axial force, the shear force and the bending moment have been obtained in order to evaluate the probability of exceeding the limit resistance.

The weight of each transversal frame, including girders and connection plates, is approximately $244 \mathrm{kN}$, the weight per constructed area is $581 \mathrm{~N} / \mathrm{m}^{2}$ and the weigth per volume is $152 \mathrm{~N} / \mathrm{m}^{3}$. The values used to represent the plastic behaviour of the members of these moment-resisting frames are shown in Table 2 and are detailed in Figure 8. This figure shows the parameters of FEMA 356 [16] and the equivalent input parameters used by the computer code RUAUMOKO [15] in the non-linear analysis. 


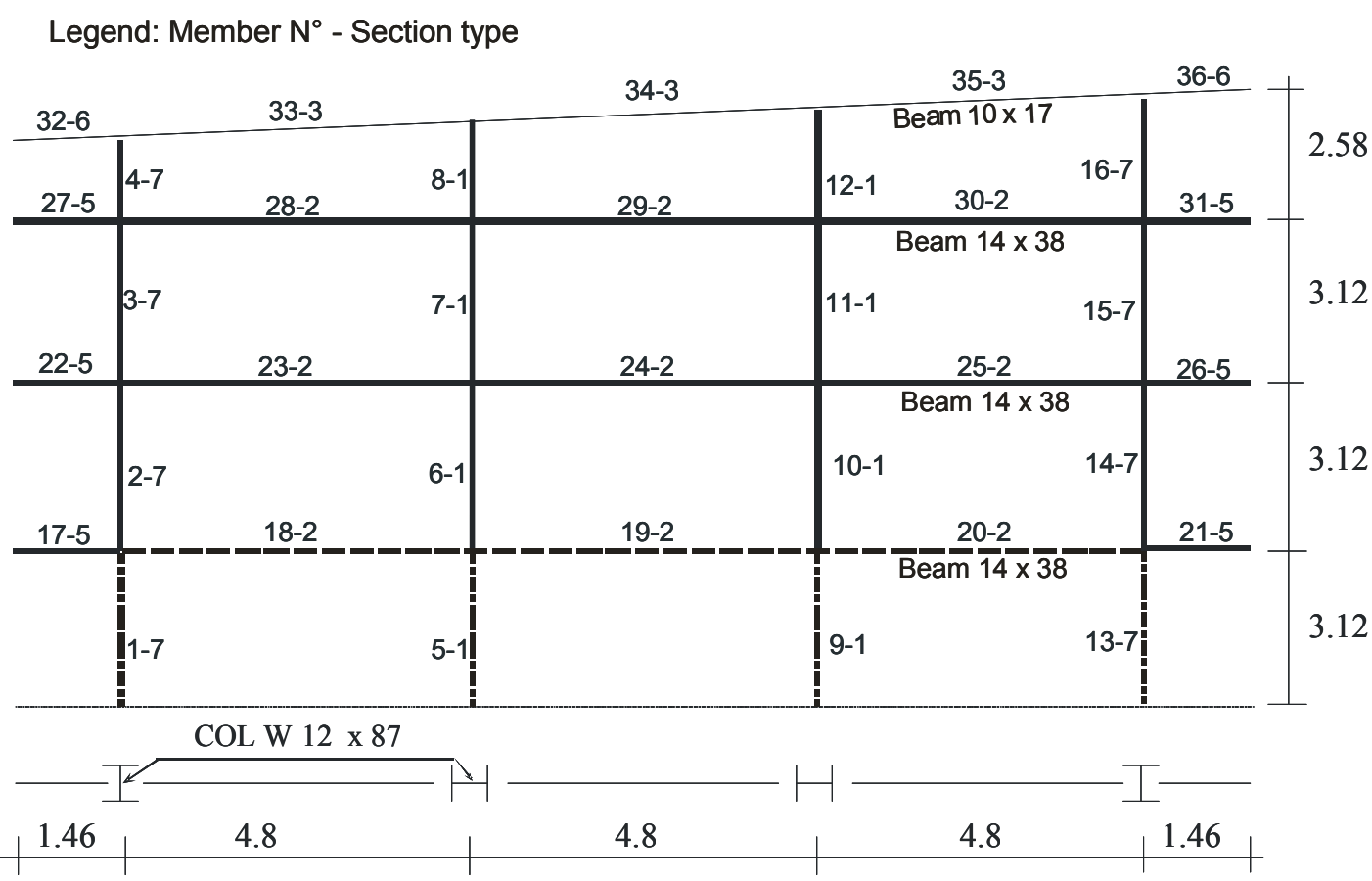

Figure 9. Moment-resisting frame

Table 2. Model parameters (see Figure 8).

\begin{tabular}{|l|c|c|c|c|c|c|c|}
\hline $\begin{array}{c}\text { Member type } \\
\text { and bending } \\
\text { axis }\end{array}$ & $\begin{array}{c}\text { Main } \\
\text { stress }\end{array}$ & $\mathbf{a}$ & $\mathbf{b}$ & $\begin{array}{c}\mathbf{c}= \\
\text { RDUCT }^{\mathbf{1}}\end{array}$ & DUCT1 $^{\mathbf{1}}$ & DUCT2 $^{\mathbf{1}}$ & DUCT3 $^{\mathbf{1}}$ \\
\hline $\mathrm{W} 12 \mathrm{x} 87, \mathrm{XX}$ & Bending & 4.89 & 7.54 & 0.20 & 5.89 & 6.19 & 8.54 \\
\hline $\mathrm{W} 12 \times 87, \mathrm{YY}$ & Bending & 4.89 & 7.54 & 0.20 & 5.89 & 6.19 & 8.54 \\
\hline $\mathrm{W} 14 \times 38, \mathrm{XX}$ & Bending & 9.00 & 11.00 & 0.60 & 10.00 & 10.20 & 12.00 \\
\hline
\end{tabular}

\subsection{Other braced frame and moment-resisting frame buildings}

In order to evaluate the structural safety of these types of steel buildings in a more general way, mid-rise and high-rise steel buildings have been also studied. The buildings have the same floor plan as those buildings analyzed in the precedent subsections and the same vertical loads, and materials properties. The same seismic actions have been considered, as well. They also fulfill all the requirements of the LRFD specification. A seven-storey building has been considered as representative of mid-rise building and a thirteen-storey building has been taken as representative of high-rise steel buildings. Thus, similar computation procedures and Monte-Carlo techniques have been applied to all the six building models which have been considered as representative of low-rise, mid-rise and high-rise braced frame and 
moment-resisting frame steel buildings. Table 3 summarizes the weight and the fundamental periods of each analyzed building.

Table 3. Weights and fundamental periods of the buildings

\begin{tabular}{|c|c|c|c|c|}
\hline \multirow{2}{*}{ Building type } & \multirow{2}{*}{$\begin{array}{c}\text { Number } \\
\text { of stories }\end{array}$} & $\begin{array}{c}\text { Weight } \\
\text { per area }\end{array}$ & $\begin{array}{c}\text { Weight } \\
\text { per volume }\end{array}$ & \multirow{2}{*}{ Period } \\
\cline { 3 - 5 } & & {$\left[\mathrm{N} / \mathrm{m}^{2}\right]$} & {$\left[\mathrm{N} / \mathrm{m}^{3}\right]$} & {$[\mathrm{s}]$} \\
\hline Low-rise moment-resisting frame & 3 & 581 & 152 & 0.64 \\
\hline Mid-rise moment-resisting frame & 7 & 736 & 232 & 0.97 \\
\hline High-rise moment-resisting frame & 13 & 936 & 297 & 1.55 \\
\hline Low-rise braced frame & 3 & 545 & 143 & 0.27 \\
\hline Mid-rise braced frame & 7 & 527 & 166 & 0.62 \\
\hline High-rise braced frame & 13 & 629 & 200 & 1.30 \\
\hline
\end{tabular}

\section{Nominal strength}

The nominal strength of the specified structural members of the studied buildings is shown in Table 4. Some of the limit values described in section 2 occur when any of these nominal values is exceeded. The maximum acceptable drift was calculated by limiting the drift index of the building to $0.9 \%$. This limit takes into account the contribution to the drift of the deflections in the two orthogonal directions of the building (see Equation 2). Similar considerations are applied to the limit value of buckling in members subjected to bending and axial compression; in this case the limit value was fixed to 0.9 (see Equation 11).

\section{Seismic demand}

According to the NSR-98 [19], the city of Manizales (Colombia) is located in a high seismic hazard area. This city is characterized by an effective peak acceleration of $0.25 \mathrm{~g}$, which is the design acceleration in units of gravity acceleration g. The following equations describe the $5 \%$ damped elastic acceleration response spectrum:

$$
S_{a}=\left\{\begin{array}{lr}
2.5 A_{a} I & \text { For } \mathrm{T}<0.48 \mathrm{~S} \\
\frac{1.2 A_{a} S I}{T} & \text { For } 0.48 \mathrm{~S}<\mathrm{T}<2.4 \mathrm{~S} \\
\frac{A_{a} I}{2} & \text { For } \mathrm{T}>2.4 \mathrm{~S}
\end{array}\right.
$$

where $S_{a}$ is the acceleration response spectrum, in units of g; $A_{a}$ is the peak effective acceleration which is also given in units of $\mathrm{g}$; $\mathrm{T}$ is the fundamental period, in 
seconds, $\mathrm{S}$ is a soil coefficient and $I$ is a factor related to the importance of the building.

Table 4. Nominal strength for members of braced frame and unbraced frame buildings

\begin{tabular}{|c|c|c|c|c|}
\hline \multirow{6}{*}{ Limit state } & \multirow{6}{*}{ Resisting parameter } & Building: & braced & unbraced \\
\hline & & Stories: & 3 & 3 \\
\hline & & Column (W): & $12 \times 53$ & $12 \times 87$ \\
\hline & & Beam $(W):$ & $12 \times 35$ & $14 \times 38$ \\
\hline & & Brace (ST): & $8 \times 4 \times 1 / 4$ & N. A. \\
\hline & & Units & & \\
\hline \multirow{3}{*}{$\begin{array}{l}\text { Tension rupture } \\
\text { of the anchor } \\
\text { rods }\end{array}$} & Distance between anchors & $\mathrm{mm}$ & 380 & 390 \\
\hline & Diameter of the anchors & $\mathrm{mm}$ & 25 & 38 \\
\hline & Limit & kN.m & 178.9 & 362.3 \\
\hline \multirow{2}{*}{$\begin{array}{l}\text { Yielding in the } \\
\text { cross section of } \\
\text { tension members }\end{array}$} & Column limit & $\mathrm{kN}$ & 2236 & 3687 \\
\hline & Brace limit & $\mathrm{kN}$ & 804.9 & N. A. \\
\hline Buckling & Limit & $\mathrm{kN}$ & 284.3 & N. A. \\
\hline \multirow{2}{*}{ Yielding } & Plastic section modulus Z & $\mathrm{m} 3$ & $8.39 \mathrm{E}-04$ & $1.01 \mathrm{E}-03$ \\
\hline & Limit & kN.m & 187.3 & 225.2 \\
\hline \multirow{3}{*}{ Shear yielding } & Height of the beam & $\mathrm{mm}$ & 318 & 358 \\
\hline & Beam web thickness & $\mathrm{mm}$ & 7.62 & 7.87 \\
\hline & Limit & $\mathrm{kN}$ & 324.4 & 378 \\
\hline \multirow{4}{*}{$\begin{array}{l}\text { Buckling in } \\
\text { members subject } \\
\text { to bending and } \\
\text { axial } \\
\text { compression }\end{array}$} & Compression limit $\varphi_{c} P_{n}$ & $\mathrm{kN}$ & 1866 & 2848 \\
\hline & Bendingl limit $\varphi_{b} \mathrm{M}_{\mathrm{nx}}$ & kN.m & 285.3 & 483 \\
\hline & Bending limit $\varphi_{b} \mathrm{M}_{\mathrm{ny}}$ & kN.m & 106.6 & 221 \\
\hline & $\begin{array}{l}\text { Bending and compression } \\
\text { interaction limit }\end{array}$ & & 0.9 & 0.9 \\
\hline \multirow{2}{*}{ Lateral deflection } & Height of the story $\mathrm{H}$ & $\mathrm{m}$ & 3.12 & 3.12 \\
\hline & Limit & $\mathrm{m}$ & 0.02808 & 0.02808 \\
\hline
\end{tabular}

In this seismic code, the buildings are classified into three groups according to the occupancy rates, the use and the hazard. The buildings analyzed herein are assigned to group II since they have a substantial public risk mainly because of their occupancy rate, which is due to their educational and university activities; for the same reason, the importance factor $I$ is set to 1.1 ; the soil is type 3 ; The rocky basement in this site is at a depth of $20 \mathrm{~m}$ while the upper soils are clay strata having typical shear wave velocities in the range between 150 and $270 \mathrm{~m} / \mathrm{s}$; therefore the site coefficient $\mathrm{S}$ is set to 1.5. These parameters define the corresponding design response spectrum. 
There are several ways of defining the ground acceleration time histories for dynamic simulations. The best way is to use real accelerograms recorded at the study site. When such data are not available, the use of synthetic accelerograms is often considered a good approach. In this work, we used a hybrid technique: a specific strong ground motion model has been developed starting from the existing accelerograms recorded in or close to the city of Manizales. This model is based on standard techniques allowing the probabilistic seismic hazard assessment and taking into account the seismic microzonation of Manizales. Therefore, it provides the necessary information about site specific response and design spectra $[20,21]$. This uniform seismic hazard spectrum was scaled using an importance factor $\mathrm{I}=1.1$. Figure 10 shows this spectrum together with the one provided by the Colombian seismic code NSR-98 [19].

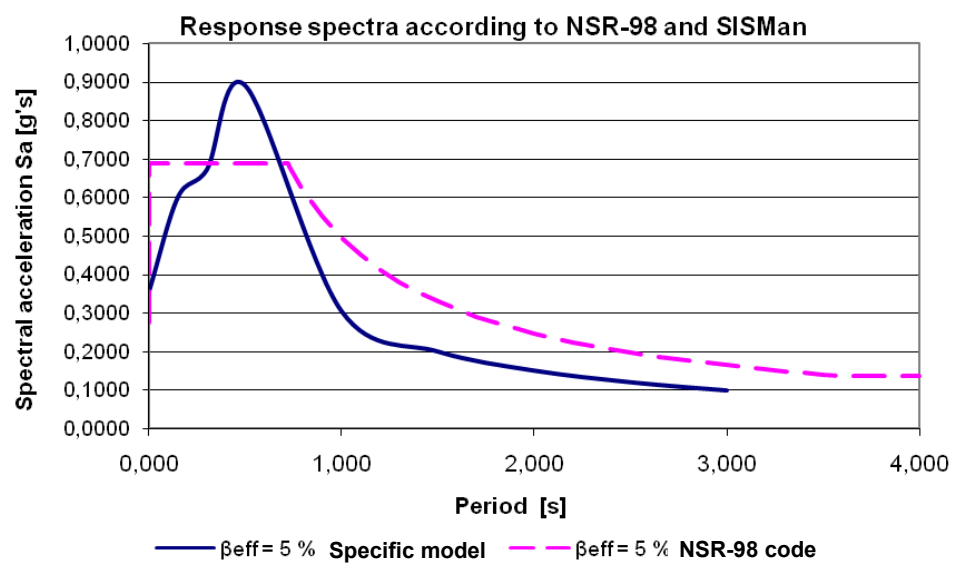

Figure10. Response spectra according to NSR-98 and to the specific model for the city of Manizales, Colombia.

\section{Monte Carlo simulation}

Monte Carlo simulation techniques are excellent tools to analyze complex processes governed by nonlinear models which, very often, can not be solved by means of analytical methods. The well-known Monte Carlo method [22] allows evaluating the significance and sensitivity of the different parameters characterizing the performance and the response of the system. This simulation is used herein for a statistical study of the behaviour of the building by using non-linear dynamic analysis. In this section, we define the random variables and we characterize the corresponding probability density functions $(p d f)$. These variables are related to key parameters of the building mechanical characteristics, of the gravity loads and of the seismic actions. 


\subsection{Mechanical properties of the materials}

The American Society for Testing and Materials (ASTM) A6 codes establishes regulations for structural steel members to be used in buildings. Table 5 shows the accepted tolerances of the main geometric characteristics of the steel members as described in Figure 11.

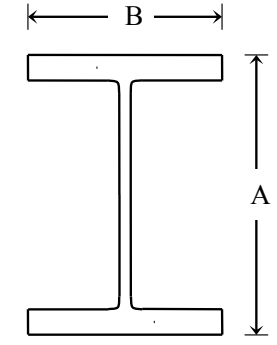

Figure 11. Main geometric characteristic of steel members
Table 5. Allowed cross section variations (see Figure 11)

\begin{tabular}{|c|c|c|c|c|}
\hline \multirow{2}{*}{ Nominal size } & \multicolumn{2}{|c|}{$\mathrm{A}(\mathrm{mm})$} & \multicolumn{2}{c|}{$\mathrm{B}(\mathrm{mm})$} \\
\cline { 2 - 5 } & $\begin{array}{c}\text { Above } \\
\text { nominal }\end{array}$ & $\begin{array}{c}\text { Below } \\
\text { nominal }\end{array}$ & $\begin{array}{c}\text { Above } \\
\text { nominal }\end{array}$ & $\begin{array}{c}\text { Below } \\
\text { nominal }\end{array}$ \\
\hline Up to $300 \mathrm{~mm}$ & 13 & 3 & 6 & 5 \\
\hline Above $300 \mathrm{~mm}$ & 3 & 3 & 6 & 5 \\
\hline \multicolumn{3}{|c}{ Area and weight allowed variation: $\pm 2,5 \%$} \\
\hline
\end{tabular}

In relation to the nominal value of a standard cross section with a height of $300 \mathrm{~mm}$, the uncertainties on the geometrical dimensions produce variability up to a $6 \%$ of the moment of inertia $i$ of the cross section. Gaussian probability density functions (pdf) are assumed with a mean value $\mu$ equal to the nominal value and with a standard deviation $\sigma$ defined by $\mu-3 \sigma=0.94 \mu$. Thus, the value $0.94 \mu$ has a probability of being reached or exceeded of $99.86 \%$, being the minimum allowed value; therefore, the obtained covariance $\sigma / \mu$ is 0.02 . This variation coefficient was also adopted for the area $a$ of the cross section and for the elasticity modulus $E$. Table 6 and Table 7 summarize the random variables and the values of the parameters corresponding to the assumed probability distributions, for braced frames and for moment-resisting frames, respectively. In these tables, $a k$ and $i k$ are, respectively, the area of the cross section and the moment of inertia of the corresponding $k$ members. The moduli of elasticity $E$ will be given in Table 9 .

Table 6. Assumed pdf functions and parameters for the areas $a k$ and moments of inertia $i k$ of the cross section of the brace frame members $k$.

\begin{tabular}{|c|c|c|c|c|}
\hline Variable & Distribution & $\mu$ & $\sigma$ & $\sigma / \mu$ \\
\hline$a 1$ & Normal & $1.06 \mathrm{E}-02$ & $2.01 \mathrm{E}-04$ & $2.0 \mathrm{E}-02$ \\
\hline$i 1$ & Normal & $1.77 \mathrm{E}-04$ & $3.54 \mathrm{E}-06$ & $2.0 \mathrm{E}-02$ \\
\hline$a 2$ & Normal & $6.64 \mathrm{E}-03$ & $1.33 \mathrm{E}-04$ & $2.0 \mathrm{E}-02$ \\
\hline$i 2$ & Normal & $1.19 \mathrm{E}-04$ & $2.37 \mathrm{E}-06$ & $2.0 \mathrm{E}-02$ \\
\hline$a 4$ & Normal & $3.61 \mathrm{E}-03$ & $7.21 \mathrm{E}-05$ & $2.0 \mathrm{E}-02$ \\
\hline$i 7$ & Normal & $3.99 \mathrm{E}-05$ & $7.97 \mathrm{E}-07$ & $2.0 \mathrm{E}-02$ \\
\hline
\end{tabular}

Concerning the yielding stress $f y$ of the structural steel, it is well known that there are significant variations of its specified minimum value which is guaranteed by the manufacturer. 
Table 7. Assumed $p d f$ functions and parameters for the areas $a k$ and moments of inertia $i k$ of the cross section of the moment frame members $k$.

\begin{tabular}{|c|c|c|c|c|}
\hline Variable & Distribution & $\mu$ & $\sigma$ & $\sigma / \mu$ \\
\hline$a 1$ & Normal & $1.65 \mathrm{E}-02$ & $3.30 \mathrm{E}-04$ & $2.0 \mathrm{E}-02$ \\
\hline$i 1$ & Normal & $3.19 \mathrm{E}-04$ & $6.37 \mathrm{E}-06$ & $2.0 \mathrm{E}-02$ \\
\hline$a 2$ & Normal & $7.23 \mathrm{E}-03$ & $1.44 \mathrm{E}-04$ & $2.0 \mathrm{E}-02$ \\
\hline$i 2$ & Normal & $1.64 \mathrm{E}-04$ & $3.23 \mathrm{E}-06$ & $2.0 \mathrm{E}-02$ \\
\hline$i 7$ & Normal & $9.63 \mathrm{E}-05$ & $1.93 \mathrm{E}-06$ & $2.0 \mathrm{E}-02$ \\
\hline
\end{tabular}

The variability of $f_{y}$ was estimated using the specifications of the Seismic Provisions for Structural Steel Buildings [23], which define the ratio $R_{y}$ of the expected yielding strength to its specified minimum value. The values of $R_{y}$ for different types of steel structural members are given in Table 8 and they provide the actual yielding moment of a steel structural shape. Therefore, it is expected a yielding stress significantly higher than the corresponding nominal value.

Table 8. Values of the factor $R_{y}$ for different types of steel structural members.

\begin{tabular}{|c|c|}
\hline Types of steel structural members & $R_{y}$ \\
\hline $\begin{array}{l}\text { Hot-rolled structural shapes and bars } \\
\begin{array}{l}\text { - ASTM A36/A36M } \\
\text { - ASTM A572/A572M Grado } 42 \\
\text { - ASTM A992/A992M } \\
\text { - All other grades }\end{array}\end{array}$ & $\begin{array}{l}1.5 \\
1.3 \\
1.1 \\
1.1\end{array}$ \\
\hline $\begin{array}{l}\text { Hollow Structural Sections } \\
\text { - ASTM A500, A501, A618 y A847 }\end{array}$ & 1.3 \\
\hline $\begin{array}{l}\text { Steel Pipe } \\
\quad \text { - ASTM A53/A53M }\end{array}$ & 1.4 \\
\hline Plates & 1.1 \\
\hline All other products & 1.1 \\
\hline
\end{tabular}

The use of the ratio $R_{y}$ is a deterministic way to establish the maximum yielding moment of the beams which guarantees that the yielding process will occur before in the beams than in the columns (weak beam-strong column principle). A probabilistic treatment of this property is described in [18], where we can find several histograms for the yield stress of different steel qualities; based on this reference, the yielding stress of the quality steel ASTM A-36 specified for the analyzed buildings has been calculated. The yielding stress is assumed to be a normal random variable with a mean $\mu=3.4 \mathrm{E}+08 \mathrm{~Pa}$ and $\sigma / \mu=9.7 \mathrm{E}-02$ (see Figure 12 and $f_{y}$ in Table 9). It is worth noting that this mean value corresponds to the minimum yield stress specified for an ASTM A-36 steel $\left(f_{y}=2.480 \mathrm{E}+08 \mathrm{~Pa}\right)$ multiplied by an average factor $R_{y}$ of 1.37. ASTM A-36 steel was used in most of the steel buildings of the second half of the $\mathrm{XX}^{\text {th }}$ century; but nowadays it is being replaced by the ASTM A-572 steel [24]. 


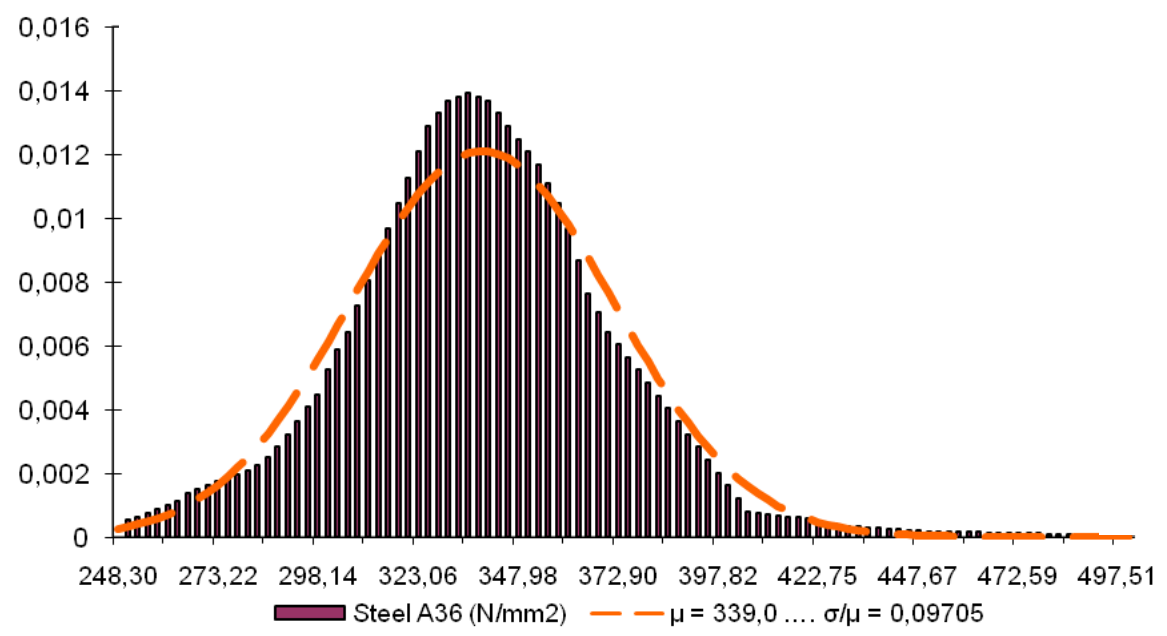

Figure 12. Histogram and fit of the assumed normal probability distribution for the yielding stress $f_{y}$ of the A-36 steel. See also reference [18].

\subsection{Gravity loads}

For the structural analysis of steel buildings, the adopted load combinations have been developed by the Subcommittee A-58 of Load Factors of the American National Standards Institute (ANSI). These combinations are based on the assumption that in a period of time of 50 years, only one of the load types will reach its maximum value while the other ones will remain around their mean value [25]. The coefficient of the dead load in such combinations, including the periods after construction, ranges between 0.9 and 1.2. From a statistical standpoint, it is possible to express this coefficient as a normal random variable with $\mu=1.05$ and $\sigma / \mu=4.696 \mathrm{E}-02$ (see $f d l$ in Table 9) [18]. On the other hand, the coefficient of live load in the ANSI combinations ranges between 0.5, associated to situations where wind, snow and earthquake are the dominant loads, and 1.6, when the live load is dominant, that is, live loads reach their maximum expected value for a time period of 50 years. In this work, the response of the structure is analyzed for a seismic action, what requires a coefficient of live loads equal to 0.5 . However, in order to give a statistical treatment to this load, a curve is fitted to the histogram provided by Marek et al. [18] corresponding to a maximum lifetime live load (see Figure 13). The function better fitting this histogram is the logistics function, which is defined as follows:

$$
p(x)=\frac{\exp \left(-\frac{x-a}{b}\right)}{b\left[1+\exp \left(-\frac{x-a}{b}\right)\right]^{2}}
$$


where $a$ and $b$ are the parameters of the distribution, which are related to the mean and standard deviation. Figure 13 displays the corresponding parameters (see also $f l l$ in Table 9).

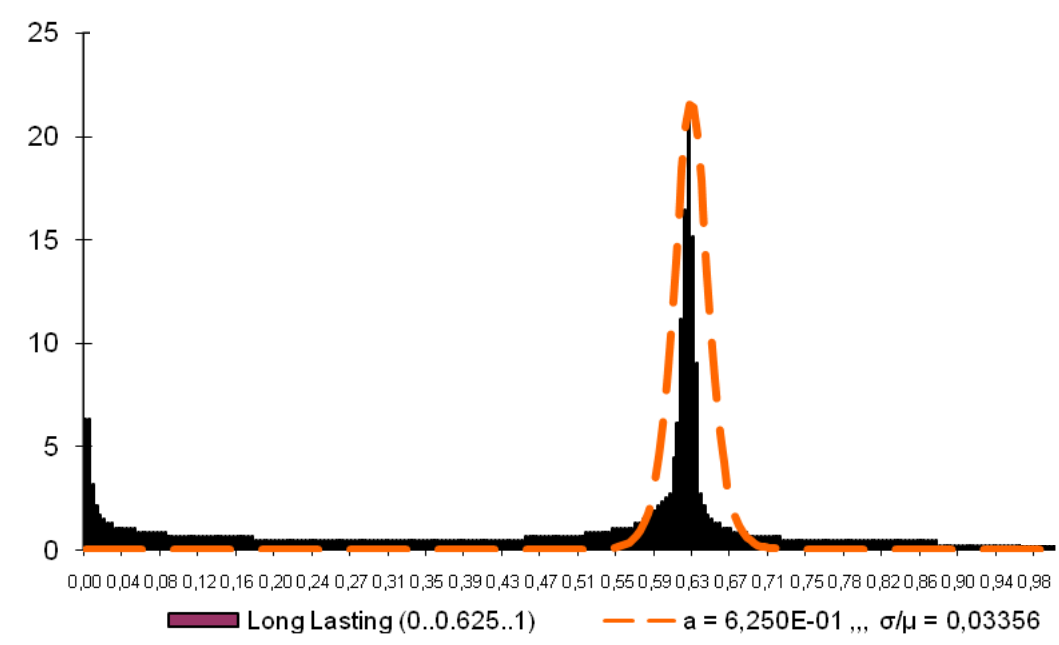

Figure 13. Histogram and logistic probability function fit for live loads (see explanation in the text).

Table 9 summarizes the assumed pdf functions and parameters for the mechanical properties of the steel, $f_{y}$ and $E$, and for the vertical loads, $f d l$ and $f l l$.

Table 9. Assumed $p d f$ functions and corresponding parameters for the mechanical properties of the steel and for the vertical loads.

\begin{tabular}{|c|l|c|c|c|c|}
\hline Variable & Distribution & $\mu$ & $\sigma$ & $\sigma / \mu$ & Parameters \\
\hline$f_{y}$ & Normal & $3.39 \mathrm{E}+08$ & $3.29 \mathrm{E}+07$ & $9.70 \mathrm{E}-02$ & \\
\hline$E$ & Normal & $2.00 \mathrm{E}+11$ & $4.00 \mathrm{E}+09$ & $2.00 \mathrm{E}-02$ & \\
\hline$f d l$ & Normal & $1.05 \mathrm{E}+00$ & $4.93 \mathrm{E}-02$ & $4.70 \mathrm{E}-02$ & \\
\hline$f l l$ & Logistic & $6.25 \mathrm{E}-01$ & $2.10 \mathrm{E}-02$ & $3.36 \mathrm{E}-02$ & $\mathrm{a}=0.625 ; \mathrm{b}=0.01156$ \\
\hline
\end{tabular}

\subsection{Seismic loads}

As pointed out above, we use a specific strong motion model developed for the city of Manizales, Colombia. Thus, the acceleration time histories used in the dynamic analyses are based on the strong motion model developed by Hurtado [17], which, in addition to the effective peak ground acceleration (epga), is defined by the following parameters: 1) the fundamental frequency associated to the soil type, $\left.\omega_{\mathrm{g}}, 2\right)$ the effective damping coefficient $v_{\mathrm{g}}$ and 3 ) the duration of the strong phase of the motion, $s_{\mathrm{o}}$ [26]. Since this model is based on real data, the accelerograms obey the 
main tectonic and geological characteristics of the region and they adequately describe the expected seismic hazard. Figure 14 shows an example of synthetic accelerogram.

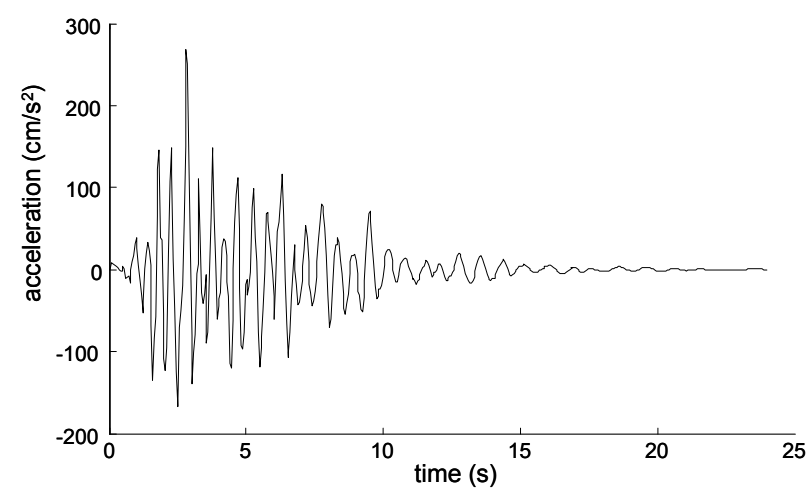

Figure 14. Sample of the simulated synthetic accelerograms.

The epga, the fundamental frequency $\omega_{\mathrm{g}}$, the damping coefficient $v_{\mathrm{g}}$ and the duration $s_{\mathrm{o}}$ are assumed to be random variables. The calculation of $s_{\mathrm{o}}$ starts from the epga and uses a new random variable $\varepsilon$ [17]. Table 10 summarizes these variables, the assumed statistical functions and the corresponding parameters. The logistic function for the epga has been defined in equation (14). In this case, and in order to establish the appropriate values of the parameters $a$ and $b$, it is necessary to estimate the value of the variation coefficient $(\sigma / \mu)$ related to the expected maximum acceleration. The value assigned to this coefficient depends on the site and it can range from 0.56 to 1.38 [27]. In Tokyo, where a great database is managed, the expected maximum soil acceleration is $0,23 \mathrm{~g}$ and $\sigma / \mu$ is equal to 0.60 [28]. In our case a value of 0.60 is assumed for the $\sigma / \mu$ related to the maximum acceleration of Manizales, for which the values of $a=0.1448$ and $b=0.04789$ have been obtained (see epga in Table 10).

Table 10. Assumed $p d f$ functions and corresponding parameters for the seismic loads.

\begin{tabular}{|c|c|c|c|c|c|}
\hline Variable & Distribution & $\boldsymbol{\mu}$ & $\boldsymbol{\sigma}$ & $\boldsymbol{\sigma} / \boldsymbol{\mu}$ & Parameters \\
\hline epga & Logistic & $1.45 \mathrm{E}-01$ & $8.69 \mathrm{E}-02$ & $6.00 \mathrm{E}-01$ & $\mathrm{a}=0.1448 ; \mathrm{b}=0.04789$ \\
\hline$\varepsilon$ & Normal & $1.00 \mathrm{E}-04$ & $2.87 \mathrm{E}-01$ & $2.87 \mathrm{E}+03$ & \\
\hline$\omega_{\mathrm{g}}$ & Weibull & $1.21 \mathrm{E}+01$ & $3.02 \mathrm{E}+00$ & $2.50 \mathrm{E}-01$ & $\mathrm{k}=1.55 ; \mathrm{w}=12.6 ; \varepsilon=7.5$ \\
\hline$\nu_{\mathrm{g}}$ & Lognormal & $1.54 \mathrm{E}-01$ & $6.20 \mathrm{E}-02$ & $4.03 \mathrm{E}-01$ & $\lambda=-1.9442 ; \varsigma=0.3865$ \\
\hline
\end{tabular}

Figure 15 show the mean 5\% damped response spectrum of the calculated sample and the mean spectrum plus three times the standard deviation together with the NSR-98 spectrum. These mean and mean $+3 \sigma$ curves correspond to a sample of two hundreds of synthetic accelerograms. 


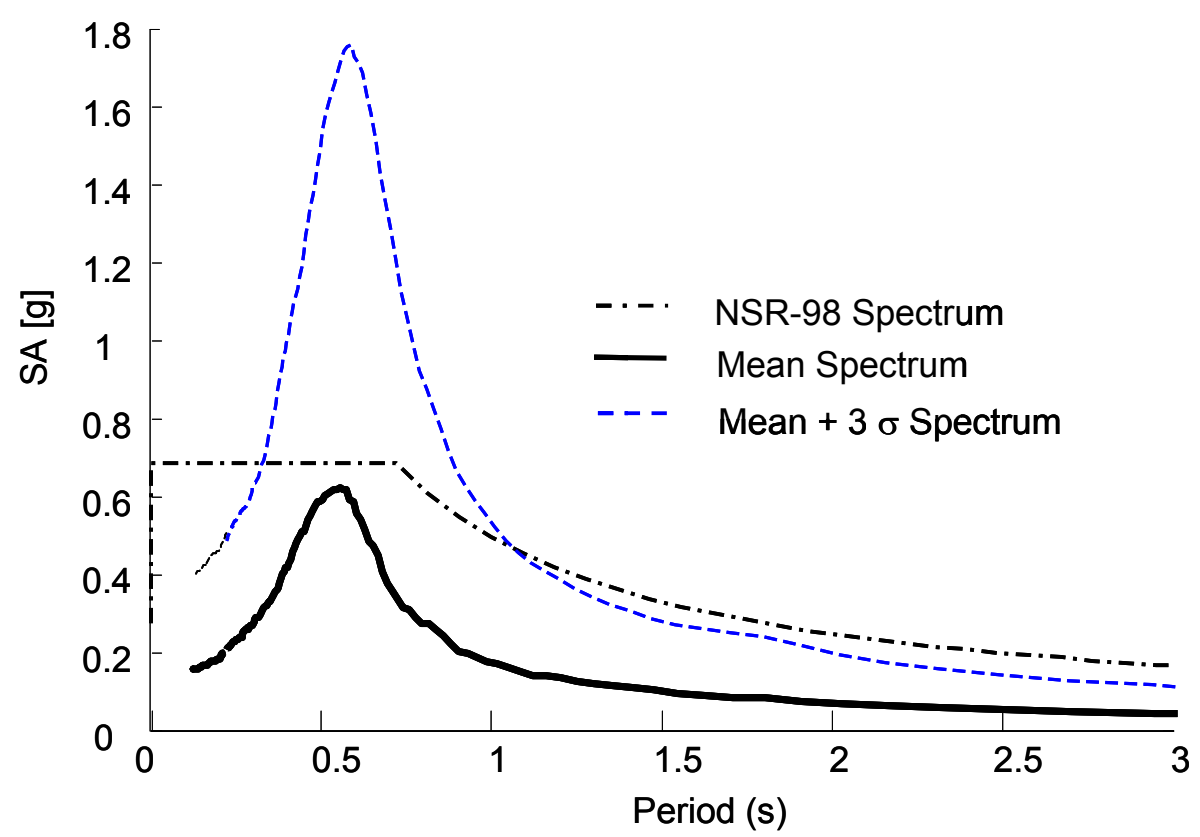

Figure 15. Response spectra of the synthetic accelerograms and design spectrum.

\section{Results of the Monte Carlo analysis}

To evaluate the probability of exceedance of the limit states described in section 2 , a Monte Carlo analysis has been performed using the STAC software [29]. This computer program carries out the random selection of samples of the variables allowing generating random collections of buildings and accelerograms compatible with the probability distributions and parameters listed in Tables 6, 7,9 and 10. It is worth noting that the statistical distributions of the input variables agree those defined in Tables 6, 7, 9 and 10. The software RUAUMOKO [15] has been used to perform the non linear analyses. Afterwards, the RUAUMOKO outputs are used for a statistical analysis.

\subsection{Braced frame buildings}

The most relevant results obtained for the braced frame building are shown in Table 11. Rows and columns of Table 11 have been numbered for an easy reference. A description of the parameters is given in an Appendix. Numbers in column 2 refer to the parameters description given in this Appendix. Figure 16 depicts the values of Table 11. Only the parameters having a significant probability of exceedance (greater or equal to 10\%) are shown. The numbers in column 7 refer to the applied equation, while column 8 shows the limit value of the corresponding variable. The last two columns show the probability to exceed these limits. Rows 6 to 8 are obtained from a post-process performed in order to evaluate the combined stresses. Row 9 shows the drift limit value corresponding to the light damage. Probabilities, 
in columns 9 and 10, are the ratios of the number of simulations in which the limit was surpassed to the total number of successful simulations (10455).

Table 11.

Monte Carlo simulation results for braced frame buildings. Among the 90 parameters tested only those with an exceedance probability greater than $10 \%$ are shown.

\begin{tabular}{|c|c|c|c|c|c|c|c|c|c|}
\hline 1 & 2 & 3 & 4 & 5 & 6 & 7 & 8 & 9 & 10 \\
\hline & Parameter & $\begin{array}{c}\text { Mean } \\
(\mu)\end{array}$ & $\begin{array}{c}\text { Standard } \\
\text { Deviation } \\
(\sigma)\end{array}$ & $\sigma / \mu$ & $\begin{array}{c}\text { Equa- } \\
\text { tions }\end{array}$ & Limit & $\begin{array}{c}\text { Excee } \\
\text {-dance } \\
\text { Proba- } \\
\text { bility }{ }^{1}\end{array}$ & $\begin{array}{c}\text { Excee } \\
\text {-dance } \\
\text { Proba } \\
\text {-bility }{ }^{2}\end{array}$ \\
\hline 1 & 1 & epga & $1.4 \mathrm{E}-1$ & $8.4 \mathrm{E}-02$ & $5.8 \mathrm{E}-01$ & & $2.5 \mathrm{E}-01$ & 0.10 & 0.10 \\
\hline 2 & 16 & axial_min_41 & $-2.1 \mathrm{E}+5$ & $9.2 \mathrm{E}+04$ & $-4.5 \mathrm{E}-01$ & 5 & $-2.8 \mathrm{E}+05$ & 0.29 & 0.07 \\
\hline 3 & 16 & axial_min_42 & $-1.7 \mathrm{E}+5$ & $9.0 \mathrm{E}+04$ & $-5.2 \mathrm{E}-01$ & 5 & $-2.8 \mathrm{E}+05$ & 0.18 & 0.03 \\
\hline 4 & 16 & axial_min_45 & $-2.0 \mathrm{E}+5$ & $9.4 \mathrm{E}+04$ & $-4.6 \mathrm{E}-01$ & 5 & $-2.8 \mathrm{E}+05$ & 0.29 & 0.07 \\
\hline 5 & 16 & axial_min_46 & $-1.7 \mathrm{E}+5$ & $9.4 \mathrm{E}+04$ & $-5.4 \mathrm{E}-01$ & 5 & $-2.8 \mathrm{E}+05$ & 0.18 & 0.03 \\
\hline 6 & 10 & H1-1a_5-1 & $6.8 \mathrm{E}-1$ & $2.1 \mathrm{E}-01$ & $3.0 \mathrm{E}-01$ & 11 & $9.0 \mathrm{E}-01$ & 0.14 & 0.02 \\
\hline 7 & 10 & H1-1a_9-1 & $6.9 \mathrm{E}-1$ & $2.0 \mathrm{E}-01$ & $3.0 \mathrm{E}-01$ & 11 & $9.0 \mathrm{E}-01$ & 0.15 & 0.03 \\
\hline 8 & 10 & H1-1a_9-2 & $6.6 \mathrm{E}-1$ & $1.8 \mathrm{E}-01$ & $2.7 \mathrm{E}-01$ & 11 & $9.0 \mathrm{E}-01$ & 0.10 & 0.02 \\
\hline 9 & 21 & displ abs max & $2.1 \mathrm{E}-3$ & $1.6 \mathrm{E}-03$ & $7.9 \mathrm{E}-01$ & & $2.5 \mathrm{E}-03$ & 0.36 & 0.36 \\
\hline
\end{tabular}

${ }^{1}$ Related to the nominal values.

${ }^{2}$ Related to the mean value of the assumed random distributions.

${ }^{3}$ Related to the slight damage limit.

Figure 16. Exceedance probabilities for the parameters of braced frame buildings (see also Table 11). 
The obtained results allow establishing the following conclusions: 1) the collection of synthetic accelerograms generated in this stochastic analysis has a probability 0.10 of exceeding the established maximum soil acceleration for Manizales $(0.25 \mathrm{~g})$. 2) Under compression, the braces of the first and second floors (see rows 2 to 5 in Table 11) show the most critical situation;

The fact that the exceedance probabilities of the nominal strength can reach values close to 0.30 indicates that the design strengths of the considered building construction code are insufficient, leading to probable failures in the connection elements (e.g. bolts, rods and welding). 3) Concerning the expected damage, only the inter-story drifts corresponding to none and slight damage show significant occurrence probabilities (36\% for the slight damage). 4) The exceedance probabilities for the other parameters listed in the Appendix are negligible showing that for those parameters, the applied design code is adequate.

Our results show that the braced frame building designed according to the LRFD specifications [14], offer the requested structural reliability; for seismic actions having a $10 \%$ probability of exceeding the design earthquake the structural damage will be very slight and it is concentrated in the bracing members. As their connections were dimensioned only for nominal tensile stresses, damages in the welding and connection screws are expected to appear. The inter-story drifts will also be low, with a mean of 0.002 . In this way, we found that the probability of reaching drift ranges that might affect non-structural elements and the external and internal infill walls is $0.02 \%$.

\subsection{Moment-resisting frame building}

The main results obtained for the moment-resisting frame building are shown in Table 12. Rows and columns have been numbered in the same way as in Table 11. The parameters are described in the Appendix. Numbers in column 2 refer to the parameters description given in this Appendix. Figure 17 depicts the values of Table 12. Only the parameters having a significant probability of exceedance (greater or equal to $10 \%$ ) are shown. The numbers in column 7 refer to the applied equation, while column 8 shows the limit value of the corresponding variable. The last two columns show the probability to exceed these limits. Rows 31 and 32 are the drift limits corresponding to the damage states. Probabilities, in columns 8 and 9, are the ratios of the number of simulations in which the limit was surpassed to the total number of successful simulations (10455). 
Table 12.

Monte Carlo simulation results for moment-resisting frame buildings. Among the 90 parameters tested only those with an exceedance probability greater than $10 \%$ are shown.

\begin{tabular}{|c|c|c|c|c|c|c|c|c|c|}
\hline 1 & 2 & 3 & 4 & 5 & 6 & 7 & 8 & 9 & 10 \\
\hline & & Parameter & Mean $(\mu)$ & $\begin{array}{l}\text { Standard } \\
\text { Deviation } \\
(\sigma)\end{array}$ & $\sigma / \mu$ & $\begin{array}{l}\text { Equa- } \\
\text { tions }\end{array}$ & Limit & $\begin{array}{l}\text { Excee } \\
\text {-dance } \\
\text { Proba- } \\
\text { bility }{ }^{1}\end{array}$ & $\begin{array}{l}\text { Excee } \\
\text {-dance } \\
\text { Proba } \\
\text {-bility }{ }^{2}\end{array}$ \\
\hline 1 & 1 & epga & $1.5 \mathrm{E}-01$ & $8.5 \mathrm{E}-02$ & $5.8 \mathrm{E}-01$ & & $2.5 \mathrm{E}-01$ & $1.0 \mathrm{E}-01$ & $1.0 \mathrm{E}-01$ \\
\hline 2 & 10 & desp_max_1 & $2.0 \mathrm{E}-02$ & $1.3 \mathrm{E}-02$ & $6.6 \mathrm{E}-01$ & 12 & $2.8 \mathrm{E}-02$ & $2.9 \mathrm{E}-01$ & $2.9 \mathrm{E}-01$ \\
\hline 3 & 10 & desp_max_2 & $2.3 \mathrm{E}-02$ & $1.4 \mathrm{E}-02$ & $6.0 \mathrm{E}-01$ & 12 & $2.8 \mathrm{E}-02$ & $3.9 \mathrm{E}-01$ & $3.9 \mathrm{E}-01$ \\
\hline 4 & 11 & desp_min_1 & $-1.9 \mathrm{E}-02$ & $1.2 \mathrm{E}-02$ & $-6.5 \mathrm{E}-01$ & 12 & $-2.8 \mathrm{E}-02$ & $2.6 \mathrm{E}-01$ & $2.6 \mathrm{E}-01$ \\
\hline 5 & 11 & desp_min_2 & $-2.2 \mathrm{E}-02$ & $1.3 \mathrm{E}-02$ & $-6.0 \mathrm{E}-01$ & 12 & $-2.8 \mathrm{E}-02$ & $3.6 \mathrm{E}-01$ & $3.6 \mathrm{E}-01$ \\
\hline 6 & 14 & mom_max_18-1 & $1.2 \mathrm{E}+05$ & $1.3 \mathrm{E}+05$ & $1.0 \mathrm{E}+00$ & 9 & $2.3 \mathrm{E}+05$ & $3.3 \mathrm{E}-01$ & $9.0 \mathrm{E}-02$ \\
\hline 7 & 14 & mom_max_18-2 & $1.2 \mathrm{E}+05$ & $1.4 \mathrm{E}+05$ & $1.2 \mathrm{E}+00$ & 9 & $2.3 E+05$ & $3.6 \mathrm{E}-01$ & $1.1 \mathrm{E}-01$ \\
\hline 8 & 14 & mom_max_19-1 & $1.3 \mathrm{E}+05$ & $1.4 \mathrm{E}+05$ & $1.0 \mathrm{E}+00$ & 9 & $2.3 \mathrm{E}+05$ & $3.8 \mathrm{E}-01$ & $1.3 \mathrm{E}-01$ \\
\hline 9 & 14 & mom_max_19-2 & $1.3 E+05$ & $1.4 \mathrm{E}+05$ & $1.1 \mathrm{E}+00$ & 9 & $2.3 E+05$ & $3.8 \mathrm{E}-01$ & $1.0 \mathrm{E}-01$ \\
\hline 10 & 14 & mom_max_20-1 & $1.2 \mathrm{E}+05$ & $1.4 \mathrm{E}+05$ & $1.1 \mathrm{E}+00$ & 9 & $2.3 \mathrm{E}+05$ & 3.7E-01 & $1.4 \mathrm{E}-01$ \\
\hline 11 & 14 & mom_max_20-2 & $1.2 \mathrm{E}+05$ & $1.3 \mathrm{E}+05$ & $1.1 \mathrm{E}+00$ & 9 & $2.3 \mathrm{E}+05$ & $3.3 \mathrm{E}-01$ & $6.1 \mathrm{E}-02$ \\
\hline 12 & 14 & mom_max_5-1 & $4.3 \mathrm{E}+05$ & $1.9 \mathrm{E}+05$ & $4.5 \mathrm{E}-01$ & 2,11 & $3.6 \mathrm{E}+05$ & $5.8 \mathrm{E}-01$ & $5.8 \mathrm{E}-01$ \\
\hline 13 & 14 & mom_max_9-1 & $4.3 E+05$ & $1.9 \mathrm{E}+05$ & $4.5 \mathrm{E}-01$ & 2,11 & $3.6 \mathrm{E}+05$ & $5.9 \mathrm{E}-01$ & $5.9 \mathrm{E}-01$ \\
\hline 14 & 15 & mom_min_18-1 & $-2.7 \mathrm{E}+05$ & $7.4 \mathrm{E}+04$ & $-2.8 \mathrm{E}-01$ & 9 & $-2.3 \mathrm{E}+05$ & $6.5 \mathrm{E}-01$ & $4.2 \mathrm{E}-01$ \\
\hline 15 & 15 & mom_min_18-2 & $-2.8 \mathrm{E}+05$ & $6.6 \mathrm{E}+04$ & $-2.4 \mathrm{E}-01$ & 9 & $-2.3 \mathrm{E}+05$ & $7.2 \mathrm{E}-01$ & $5.0 \mathrm{E}-01$ \\
\hline 16 & 15 & mom_min_19-1 & $-2.8 \mathrm{E}+05$ & $6.9 E+04$ & $-2.5 \mathrm{E}-01$ & 9 & $-2.3 \mathrm{E}+05$ & $7.1 \mathrm{E}-01$ & $4.8 \mathrm{E}-01$ \\
\hline 17 & 15 & mom_min_19-2 & $-2.8 \mathrm{E}+05$ & $6.7 \mathrm{E}+04$ & $-2.4 \mathrm{E}-01$ & 9 & $-2.3 \mathrm{E}+05$ & $7.2 \mathrm{E}-01$ & $5.0 \mathrm{E}-01$ \\
\hline 18 & 15 & mom_min_20-1 & $-2.8 \mathrm{E}+05$ & $6.8 \mathrm{E}+04$ & $-2.5 \mathrm{E}-01$ & 9 & $-2.3 \mathrm{E}+05$ & $7.1 \mathrm{E}-01$ & $4.8 \mathrm{E}-01$ \\
\hline 19 & 15 & mom_min_20-2 & $-2.7 \mathrm{E}+05$ & $7.2 \mathrm{E}+04$ & $-2.7 \mathrm{E}-01$ & 9 & $-2.3 \mathrm{E}+05$ & $6.6 \mathrm{E}-01$ & 4.4E-01 \\
\hline 20 & 15 & mom_min_5-1 & $-4.4 \mathrm{E}+05$ & $1.9 \mathrm{E}+05$ & $-4.3 \mathrm{E}-01$ & 2,11 & $-3.6 \mathrm{E}+05$ & $6.0 \mathrm{E}-01$ & $6.0 \mathrm{E}-01$ \\
\hline 21 & 15 & mom_min_9-1 & $-4.4 \mathrm{E}+05$ & $1.9 \mathrm{E}+05$ & $-4.3 \mathrm{E}-01$ & 2,11 & $-3.6 \mathrm{E}+05$ & $6.0 \mathrm{E}-01$ & $6.0 \mathrm{E}-01$ \\
\hline 22 & 20 & H1-1a_1-1 & $9.8 \mathrm{E}-01$ & 4.0E-01 & $4.0 \mathrm{E}-01$ & 11 & $9.0 \mathrm{E}-01$ & $5.5 \mathrm{E}-01$ & $3.4 \mathrm{E}-01$ \\
\hline 23 & 20 & H1-1a_1-2 & $7.3 \mathrm{E}-01$ & $2.8 \mathrm{E}-01$ & $3.9 \mathrm{E}-01$ & 11 & $9.0 \mathrm{E}-01$ & 3.3E-01 & $4.8 \mathrm{E}-02$ \\
\hline 24 & 20 & H1-1a_5-1 & $1.1 \mathrm{E}+00$ & $3.5 \mathrm{E}-01$ & $3.2 \mathrm{E}-01$ & 11 & $9.0 \mathrm{E}-01$ & $6.4 \mathrm{E}-01$ & 4.3E-01 \\
\hline 25 & 20 & H1-1a_5-2 & $6.9 \mathrm{E}-01$ & $2.2 \mathrm{E}-01$ & $3.1 \mathrm{E}-01$ & 11 & $9.0 \mathrm{E}-01$ & $1.7 \mathrm{E}-01$ & $7.4 \mathrm{E}-03$ \\
\hline 26 & 20 & H1-1a_9-1 & $1.1 \mathrm{E}+00$ & $3.5 \mathrm{E}-01$ & $3.2 \mathrm{E}-01$ & 11 & $9.0 \mathrm{E}-01$ & $6.4 \mathrm{E}-01$ & $4.3 \mathrm{E}-01$ \\
\hline 27 & 20 & H1-1a_9-2 & $6.9 \mathrm{E}-01$ & 2.2E-01 & $3.2 \mathrm{E}-01$ & 11 & $9.0 \mathrm{E}-01$ & $1.8 \mathrm{E}-01$ & $6.9 \mathrm{E}-03$ \\
\hline 28 & 20 & H1-1a_13-1 & $9.9 \mathrm{E}-01$ & $3.9 \mathrm{E}-01$ & $3.9 \mathrm{E}-01$ & 11 & $9.0 \mathrm{E}-01$ & $5.6 \mathrm{E}-01$ & $3.4 \mathrm{E}-01$ \\
\hline 29 & 20 & H1-1a_13-2 & $7.4 \mathrm{E}-01$ & $2.7 \mathrm{E}-01$ & $3.7 \mathrm{E}-01$ & 11 & $9.0 \mathrm{E}-01$ & $3.3 \mathrm{E}-01$ & $4.3 \mathrm{E}-02$ \\
\hline 30 & 21 & despl abs max & $2.4 \mathrm{E}-02$ & $1.5 \mathrm{E}-02$ & $6.2 \mathrm{E}-01$ & & $2.8 \mathrm{E}-02$ & $4.1 \mathrm{E}-01$ & 4.1E-01 \\
\hline 31 & 22 & Slight damage & 2.4E-02 & $1.5 \mathrm{E}-02$ & $6.2 \mathrm{E}-01$ & & $1.6 \mathrm{E}-02$ & $6.7 \mathrm{E}-01$ & $6.7 \mathrm{E}-01$ \\
\hline 32 & 23 & Moderate damage & 2.4E-02 & $1.5 \mathrm{E}-02$ & $6.2 \mathrm{E}-01$ & & $3.6 \mathrm{E}-02$ & 2.4E-01 & 2.4E-01 \\
\hline
\end{tabular}

${ }^{1}$ Related to the nominal values.

${ }^{2}$ Related to the mean value of the assumed random distributions. 
Figure 17. Exceedance probabilities for the parameters of moment-resisting frame buildings (see also Table 12).

In spite of being designed to satisfy the strength and deformation requirements of the LRFD specification [14], this building has up to a $40 \%$ of probability to exceed the allowed lateral deformation during a seismic event, showing significant damage in the drift-sensitive non-structural elements. The probability of exceeding the capacity of the column anchorage to foundation (see Figure 1) is about $60 \%$ (see rows 12 and 13 in Table 12). This situation is in agreement with the fact that the first story columns (members 1, 5, 9 and 13 in Figure 10) have a high probability of yielding at their base due to the combination of tensile stresses produced by axial forces and bending moments (see rows 22, 24, 26 and 28 in Table 12). Concerning the expected damage, the probabilities of the inter-story drifts corresponding to slight and moderate damage are $67 \%$ and $24 \%$ respectively. Reaching the moderate damage state implies the beginning of yielding in all the bearings. The yielding probability of the first story beam extremities (members 18, 19 and 20 in Figure 10) 
exceeds the $40 \%$. The probabilities of the inter-story drift limits corresponding to severe and collapse are negligible. Then we can conclude that the moment-resisting frame building do not offers the requested structural reliability; moderate damage is expected for the design earthquake with significant structural damage mainly located in the column anchorage to foundation and in the columns and beams of the first story. The expected inter-story drifts will be significant and the probability of reaching drift ranges that might damage the external and internal infill walls is over $40 \%$.

\subsection{Other braced frame and moment-resisting frame buildings}

The analysis of mid-rise and high-rise steel buildings leads to similar results. The braced frame buildings have the performance foreseen in the seismic design code. For the moment-resisting frame buildings, some of the design values of the parameters listed in the Appendix (e.g. the bending moments in the columns and beams of the first floor) reach exceedance probabilities of $60 \%$; thus, the safety conditions are not assured for these structures. To guarantee the claimed performance, the moment-resisting frame buildings require a 2.7 safety factor for the column anchorages to the foundations.

\subsection{Correlation analysis}

Pearson's correlation is a good tool to quantify the relationship between input and output parameters, allowing performing a sensitivity analysis of their influence on the structural safety. Only the results obtained for the braced frame buildings are discussed herein, since they are also representative for the other analyzed cases. As we have seen above, the critical outputs are the inter-story drifts of the first and second floors and the absolute value of the maximum drift of the building. Therefore our discussion is focused on these parameters. Figure 18 shows the correlation coefficients between the input variables and the expected inter-story drifts of the before mentioned floors. The parameter most affecting the output is the effective peak ground acceleration (epga). The mean and covariance values of the Pearson correlation coefficients between epga and the drifts are $\mu=0.71$ and $\sigma / \mu=0.12$ respectively. Among the other parameters involved in the definition of the ground motion model (the effective damping, $v$, and the predominant frequency, $\omega_{\mathrm{g}}$, of the soil and the parameter and $\varepsilon$, related to the duration of the ground motion), $\omega_{\mathrm{g}}$ also shows a significant correlation. In this case, the corresponding mean and covariance values are $\mu=0.37$ and $\sigma / \mu=0.16$.

Although the global influence of the other input parameters is not relevant, it is worth noting the cases of the yielding stress, $f y$, of the structural steel and the dead loads coefficients, $f d l$ and $f l l$. The correlation coefficient between $f y$ and the axial forces in critical members may take values of about 0.3 indicating that the yielding stress of the steel may have a considerable influence on the compressive tensile stresses. In some specific cases, the vertical dead and live loads may significantly 
influence the forces affecting some structural members. For instance, for the midrise moment-resisting buildings the correlation coefficient between the axial force of the central column and the dead loads, $f d l$, and live loads, $f l l$, are 0.83 and 0.18 respectively. This fact may indicate that the influence of the seismic loads in central columns is lower, affecting more their bending moments than their axial loads. A similar effect has been observed in the shear forces developed in the central beams of the high stories of the high-rise braced frame buildings; in this case, the correlation coefficients of $f d l$ and $f l l$ are 0.79 and 0.15 , respectively. Thus we conclude that the seismic loads are the main responsible for the structural response, but their influence on the bending moments and shear forces is more important in the lateral beams and columns than in the central ones.

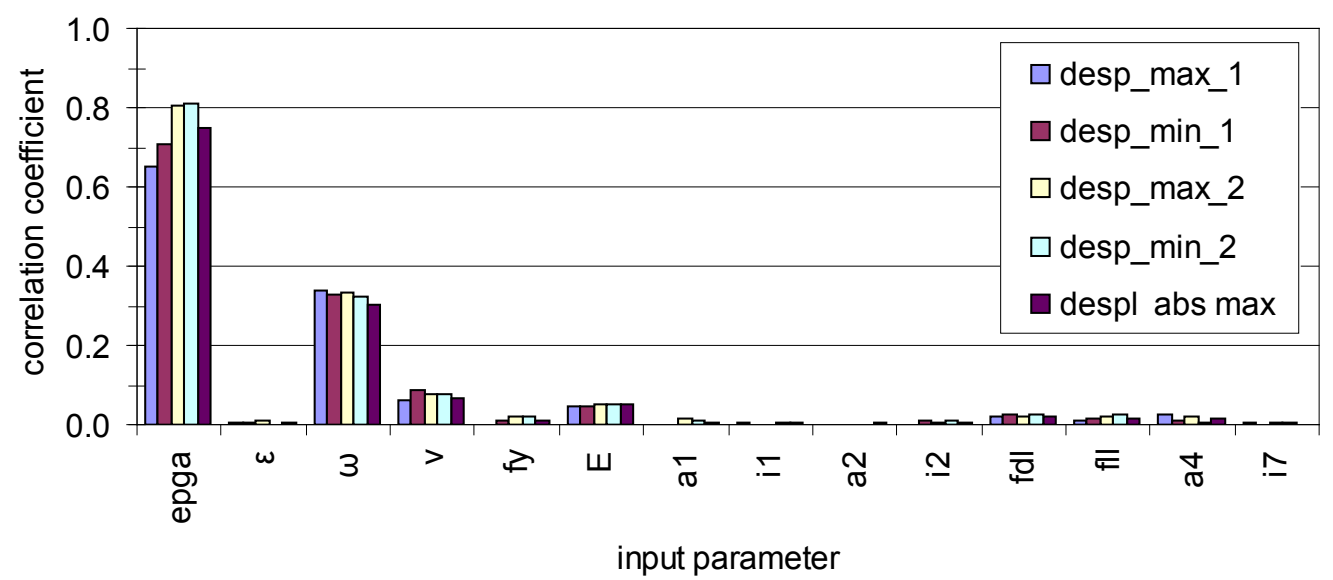

Figure 18. Pearson's correlation coefficients between the input variables and the expected inter-story drifts of the first and second floors and the maximum drift of the building.

\section{Discussion and conclusions}

The main objective of this chapter is to evaluate two alternative design solutions for an existing building in Manizales, Colombia. These design proposals are the moment-resisting frame and the braced frame structures. We have seen that the structural solution which increases the stiffness of the building by means of concentric braces is more adequate and economically interesting. This solution is $5.4 \%$ cheaper than the solution based on increasing the stiffness by using beams and columns with larger cross sections. In order to have a wider view of the performance of both types of steel building designed according to the LRFD specifications, midrise and high-rise braced and moment-resisting frame buildings have been also studied and the main results discussed.

In all the studied cases the seismic safety of the structures has been analyzed by using accelerograms with a $10 \%$ probability of exceeding the 475 year return period 
earthquake, that is, the design earthquake. A specific ground motion model for the area of study has been used to provide a wide collection of accelerograms needed for the Monte Carlo simulations.

A detailed seismic analysis of the braced frame steel building has shown that the structure fulfils the seismic safety requirements according to the LRFD specifications used in its design. Thus, it is expected that the building resist seismic motions compatible with the design earthquake without suffering significant damage. The expected drifts are negligible. The braces could suffer minor damage in the case that connections were calculated taking into account their yielding stress. On the contrary, if such connections were calculated taking into account the nominal stress, welding and connection rods and bolts could suffer extensive damage.

A similar analysis performed for the same steel building but designed without braces has shown that the structure do not fulfils the seismic safety requirements of the LRFD specifications. This means that drifts would be significant and damage would occur in beams, columns and anchorage to foundations. The probability of damage in walls as well as in other non structural elements sensitive to lateral deflections would be also significant (40\%). The probability of exceeding the slight and moderate damage drift limits are 56 and $20 \%$ respectively. There is no significant probability of reaching the extensive and complete damage drift limits. In spite of the great amount of simulations performed in our Monte Carlo analysis, the errors in all our results are less than $1 \%$. The analysis of mid-rise and high-rise steel buildings leads to similar results.

The performance of the braced frame buildings is in agreement with the specifications of the seismic design code. In the case of moment-resisting frame structures, the safety limits of the bending moments in the columns and beams of the first floor are exceeded with a probability of $60 \%$. We have observed that a 2.7 safety factor for the column anchorages to the foundations would guarantee the required structural seismic performance.

\section{Acknowledgements}

This work has been partially sponsored by the Geological Institute of Catalonia (IGC), by the Science and Education Ministry of Spain, by the European Commission and with FEDER grants through the research projects CGL-200504541-C03-02/BTE, CGL2008-00869/BTE, HABITAT-2030-PSS-380000-2005-14, SEDUREC-CONSOLIDER-CSD2006-00060, INTERREG: POCTEFA 2007-2013/ 73/08 and MOVE- FT7-ENV-2007-1-211590. 


\section{References}

[1] Yépez F., Barbat A. H. and J. A. Canas (1996). Simulación de escenarios del daño sísmico en zonas urbanas", Revista internacional de métodos numéricos para cálculo y diseño en ingeniería, 12(3), 1996, 331-358.

[2] Barbat A. H., Mena U. and F. Yépez, (1998). Evaluación probabilista del riesgo sísmico en zonas urbanas, Revista internacional de métodos numéricos para cálculo y diseño en ingeniería, 14(2), 1998, 247-268.

[3] Barbat A.H., Lagomarsino S., and L.G. Pujades (2006a). Vulnerability assessment of dwelling buildings. Capter 6 in: Assessing and Managing Earthquake Risk. Editors: Oliveira C.S., Roca A. and X. Goula Ed. Springer. Dordrecht. The Netherlands. pp. 115-134. ISBN: 10: 1-40203524-1 (HB). 13: 978-1-4020-3524-1 (HB). 10:1-4020-3608-6 (e_book) 13: 978-1-4020-3608-8 (e_book).

[4] Barbat A. H, Pujades L.G and N. Lantada (2006b) Performance of buildings under earthquake in Barcelona, Spain. Computer-Aided Civil and Infrastructure Engineering. Vol. 21: 573-593.

[5] Barbat A.H, Pujades L.G and N. Lantada (2008) Seismic damage evaluation in urban areas using the capacity spectrum method: application to Barcelona. Soil Dynamics and Earthquake Engineering, special issue: urban earthquake hazard and damage assessment, 28 (10-11): 851-865.

[6] Barbat AH, Carreño ML, Pujades LG, Lantada N, Cardona OD, Marulanda MC (2009) Seismic vulnerability and risk evaluation methods for urban areas. A review with application to a pilot area. Structure and Infrastructure Engineering, DOI: 10.1080/15732470802663763.

[7] Carreño M.L., Cardona O.D. and A.H. Barbat AH (2007) Urban seismic risk evaluation: A holistic approach, Natural Hazards, 40, 137-172.

[8] Lantada N., Pujades L.G and Barbat A.H. (2008) Vulnerability index and capacity spectrum based methods for urban seismic risk evaluation. A comparison. Natural Hazards. DOI:10.1007/s11069-007-9212-4.

[9] Moreno R, Bairán J.M., Pujades L.G, Aparicio A.C and A.H.Barbat (2004). Evaluación probabilista del comportamiento sísmico de edificios porticados de hormigón armado, Hormigón y acero, 231: 125-136.

[10] Vielma J.C, Barbat A.H and S. Oller (2008) Comportamiento sísmico de edificios de hormigón armado de ductilidad limitada, Hormigón y acero, 248, 87-101.

[11] Milutinovic Z. V. and G. S. Trendafiloski (2003). WP4: Vulnerability of current buildings. Risk-UE project Handbook. September 2003. Risk-UE project report. $111 \mathrm{pp}$. 
[12] Faber M. H, ed. (2008). Risk Assessment in Engineering Principles, System Representation \& Risk Criteria. JCSS Joint Committee of Structural Safety. ISBN 978-3-909386-78-9. Available at the web page: http://www.jcss.ethz.ch/publications/JCSS_RiskAssessment.pdf. Last accessed may 8, 2009.

[13] Faber M. H, and A.C.W.M. Vrouwenvelder (2008). Interpretation of Uncertainties and Probabilities in Civil Engineering Decision Analysis. JCSS Joint Committee of Structural Safety. http://www.jcss.ethz.ch/default.html Last accessed may 8, 2009.

[14] AISC. "Load and Resistance Factor Design (LRFD) Manual of Steel Construction”, American Institute of Steel Construction, Chicago, IL, USA, 1994.

[15] Carr J. A. "Ruaumoko3d- Inelastic Dynamic Analysis Program”, Dept. of Civil Engineering, University of Canterbury, Christchurch, New Zealand, 2002.

[16] FEMA. "Prestandard and Commentary for the Seismic Rehabilitation of Buildings" (FEMA 356), Federal Emergency Management Agency. Washington, D.C., the USA, 2000.

[17] Hurtado J. E. "Modelación estocástica de la acción sísmica”, Centro Internacional de Métodos Numéricos en Ingeniería (CIMNE), Barcelona, España, 1999.

[18] Marek P., Gustar M. and Anagnos T. "Simulation-Based Reliability Assessment for Structural Engineers”. Boca Raton, Florida, USA, 1996.

[19] AIS. "Normas Colombianas de Diseño y Construcción Sismo Resistente NSR98”, Asociación Colombiana de Ingeniería Sísmica, Bogotá, D. C., COLOMBIA, 1998.

[20] ITEC. "Sistema de información Sísmica para Manizales" (SISMan, versión 1.1.0), Ingeniería Técnica y Científica Limitada, Manizales, CDS., Colombia, 2004.

[21] CIMOC. "Microzonificación Sísmica de la Ciudad de Manizales”, Centro de Investigación en Materiales y Obras Civiles, Universidad de los Andes, Bogotá, D. C., Colombia, 2002.

[22] Tarantola A. Inverse Problem Theory. Society for Industrial and Applied Mathematics. Philadelphia, 2005.

[23] AISC. "Seismic Provisions for Structural Steel Buildings", American Institute of Steel Construction. Chicago, IL., USA, 1992.

[24] Bjorhovde R. "Development and use of high performance steel", Journal of Constructional Steel Research 60, pp 393-400, 2004. 
[25] Bermúdez C. Curso Básico de Estructuras Metálicas, Universidad Nacional de Colombia Sede Manizales, Manizales, Colombia, 2005.

[26] Bonett, R. L. "Vulnerabilidad y Riesgo Sísmico de Edificios. Aplicación a Entornos Urbanos en Zonas de Amenaza Alta y Moderada”. Tesis Doctoral. Universidad Politécnica de Cataluña, Barcelona, ESPAÑA, 2003.

[27] Bertero R. and Bertero V. "Performance-based seismic engineering: the need for a reliable conceptual comprehensive approach", Earthquake Engng Struct. Dyn., 31, pp 627-652, 2002.

[28] Foliente G. C., Paevere P. J., Saito T and Kawai, N. "Seismic Capacity Rating and Reliability Assessment of Wood Shear Walls", Proceedings of the $6^{\text {th }}$ World Conference on Timber Engineering, British Columbia, Canada, 2000.

[29] CIMNE. STAC Stochastic Analysis Computation. Centro Internacional de Métodos Numéricos en Ingeniería, Universidad Politécnica de Cataluña, Barcelona, España, 2002. 


\section{Appendix}

\begin{tabular}{|c|c|c|}
\hline Number & Parameter & Description \\
\hline 1 & epga & Effective peak ground acceleration. \\
\hline 2 & $\varepsilon$ & $\begin{array}{l}\text { Random variable related to the duration of the strong phase of } \\
\text { the motion, } \mathrm{s}_{\mathrm{o}} \text {. }\end{array}$ \\
\hline 3 & $\omega_{\mathrm{g}}$ & Fundamental frequency associated to the soil type. \\
\hline 4 & $v_{\mathrm{g}}$ & Effective damping coefficient of the soil. \\
\hline 5 & ak & Area of the cross section of the frame members $\mathrm{k}$. \\
\hline 6 & fy & yielding stress fy of the structural steel. \\
\hline 7 & $\mathrm{E}$ & modulus of elasticity of steel. \\
\hline 8 & fdl & coefficient of the dead load. \\
\hline 9 & fll & maximum lifetime live load. \\
\hline 10 & desp_max_i & Maximum drift of story i. \\
\hline 11 & desp_min_i & Minimum drift of story i. \\
\hline 12 & comp_max_i & Maximum compressive stress in element $i$. \\
\hline 13 & trac_max_i & Maximum tensile stress in element $i$. \\
\hline 14 & mom_max_i-j & $\begin{array}{l}\text { Maximum bending moment in element } i \text { at the } j \text { end of the } \\
\text { element. }\end{array}$ \\
\hline 15 & mom_min ${ }_{-} \mathrm{i}-\mathrm{j}$ & $\begin{array}{l}\text { Minimum bending moment in element } i \text { at the } j \text { end of the } \\
\text { element. }\end{array}$ \\
\hline 16 & axial_max_i & Maximum axial force in element $i$. \\
\hline 17 & axial_min_i & Minimum axial force in element $i$. \\
\hline 18 & cort_max_i-j & Maximum shear force in element $\mathrm{i}$ at the $\mathrm{j}$ end of the element. \\
\hline 19 & cort_min_i-j & Minimum shear force in element $i$ at the $j$ end of the element. \\
\hline 20 & H1-1a_i-j & $\begin{array}{l}\text { Sum of the combination of tensile stresses in member } i \text { at the } j \\
\text { end of the element. }\end{array}$ \\
\hline 21 & disp_abs_max & Absolute value of the maximum drift of the building. \\
\hline 22 & Slight D & Slight damage threshold. \\
\hline 23 & Mod D & Moderate damage threshold. \\
\hline 24 & Ext D & Extensive damage threshold. \\
\hline 25 & Collap D & Collapse damage threshold. \\
\hline
\end{tabular}

